\title{
Structural characteristics of the halite fabric type 'Kristallbrocken' from the Zechstein Basin with regard to its development
}

\author{
Yvonne Küster $\cdot$ Bernd Leiss $\cdot$ Michael Schramm
}

Received: 24 January 2008/ Accepted: 22 November 2008/Published online: 17 December 2008

(C) The Author(s) 2008. This article is published with open access at Springerlink.com

\begin{abstract}
The Kristallbrocken are a characteristic centimetre- to decimetre-sized, laminated halite fabric type occurring in the Stassfurt Formation in the Zechstein Basin. Up to now, the nature of the Kristallbrocken, i.e. if they are relics of fine-grained, polycrystalline halite beds or clasts of 'single crystal-layers', as well as the deformation mechanisms of this halite type, were not clear from the literature. Drill core material from the salt deposit Teutschenthal at the southern rim of the Zechstein Basin now allowed investigating less intensely deformed samples for the first time. The deformational behaviour of these Kristallbrocken ranges from brittle to ductile, which is evidenced by fractured Kristallbrocken on the one hand and weakly bent or even folded Kristallbrocken on the other hand. Local X-ray texture measurements demonstrated that the Kristallbrocken are definitely single crystals and that they can be regarded as relics of formerly larger 'single crystal-layers' of up to several $\mathrm{dm}^{2}$ in size. The folded Kristallbrocken clearly display by their single grain texture characteristics that their crystal lattice is bent, which was most likely enabled by a kind of flexural-shear folding, and did not develop after deformation from a finegrained aggregate by recrystallisation. Due to their monocrystallinity, their originally large size, and the solid inclusions forming the internal lamination, the Kristallbrocken have clearly stronger rheological properties than
\end{abstract}

Y. Küster $(\bowtie) \cdot$ M. Schramm

Bundesanstalt für Geowissenschaften und Rohstoffe,

Stilleweg 2, 30655 Hannover, Germany

e-mail: yv_kuester@yahoo.de

B. Leiss

Geowissenschaftliches Zentrum der Universität Göttingen,

Goldschmidtstr. 3, 37077 Göttingen, Germany the surrounding fine- to coarse-grained polycrystalline rock salt, and thus also deform by fracturing.

Keywords Halite $\cdot$ Zechstein salt $\cdot$ Kristallbrocken · X-ray texture goniometry - Deformation mechanism . Crystallography

\section{Introduction}

The rock salt of the Stassfurt Formation in Northern and Eastern Germany is of particular significance due to its relevance as host rock for hydrocarbon storage caverns (e.g. Hofrichter 1972, 1974; Jagsch and Theylich 1999; Wilke et al. 2002) and as host rock for the disposal of radioactive waste (Jaritz 1983, 1993; Bornemann 1987). Therefore, it has been subjected to numerous studies concerning stratigraphy, bromide distribution, and deformation characteristics (Schulze 1958, 1960; Jung 1968; Simon and Haltenhof 1970; Simon 1972; Bachmann 1985; Popp et al. 1999, 2001; Herrmann 2000; Bornemann et al. 2000; Schramm et al. 2005; Küster et al. 2007a). The present study focuses on a certain halite type of the Stassfurt rock salt, referred to as Kristallbrocken (German: 'Kristallbrocken' $=$ crystal fragments; Simon 1972; Fig. 1a), which has been mentioned in several previous publications and appears to be characteristic for the salt deposits of the Zechstein Basin (Fig. 2). It predominantly occurs in the Stassfurt Formation rock salts of Germany (e.g. RichterBernburg 1955; Lotze 1957; Simon and Haltenhof 1970; Simon 1972) and the Netherlands as well as in the Oldest and Older Halite (equivalent to Werra and Stassfurt Formation respectively) of Poland (Czapowski 1986, 1987; Czapowski et al. 1990, 1993). The formation of this halite type has been discussed for many decades (Schünemann 


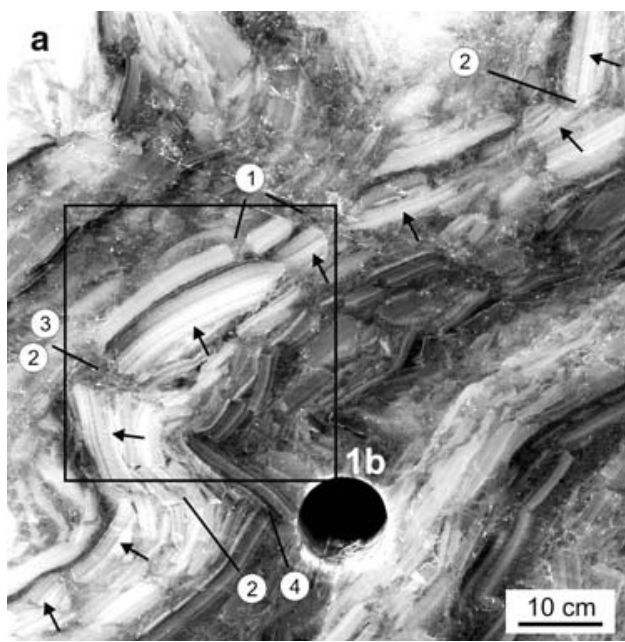

Fig. 1 a Photograph of a polished Stassfurt rock salt slab cut from a salt deposit in Northern Germany (Asse salt mine) showing the individual Kristallbrocken pieces (arrows) of an earlier coherent layer broken and pulled apart during folding. This resulted in welldeveloped boudinage structures with recrystallisation and/or solutionprecipitation in the necking areas (1) of the Kristallbrocken pieces. While the extension area of the folded layer is broken (2) and the opened space is filled with recrystallised and/or precipitated salt (3), in the compression area, a beginning stacking of the Kristallbrocken can be observed (4). b Scaled-up section of a. The Kristallbrocken in

1913; Lachmann 1914; Lotze 1957; Richter-Bernburg 1955; Schauberger and Kühn 1959; Simon 1972), but is still not fully understood.

A characteristic feature of these centimetre-sized Kristallbrocken is the internal lamination (Fig. 1b) that is defined by variations in sulphate inclusion content (e.g. Simon 1972; Czapowski 1986; Küster et al. 2007b). These inclusions can be relatively large, with sizes of about $100 \mu \mathrm{m}$, partially up to $600 \mu \mathrm{m}$ (Küster et al. 2007b). Another distinctive feature is that some of these sulphate aggregates are enclosed by a certain amount of brine (Küster et al. 2007b), a feature that has not yet been reported from other halite types. Due to the lamination, the Kristallbrocken resemble laminated sedimentary rocks as for instance layered mudstones, or sandstones, as well as the bedded or laminated halite described, for example, in Anderson et al. (1972), Schreiber et al. (1976), or Kendall (1992). From this fact, the Kristallbrocken are considered as relics of formerly continuous sedimentary halite beds (Schünemann 1913; Richter-Bernburg 1955). However, the individual layers of the above mentioned bedded or laminated halite beds are composed of numerous grains, whereas the internally laminated Kristallbrocken do not show any macroscopically visible grain boundaries inside.

Simon (1972) described the Kristallbrocken as $1-5 \mathrm{~cm}$ thick and up to $30 \mathrm{~cm}$ long, in cross section-view bricklike, sometimes oval-shaped, and opaque to transparent salt crystals, with the long axes oriented parallel to the bedding.

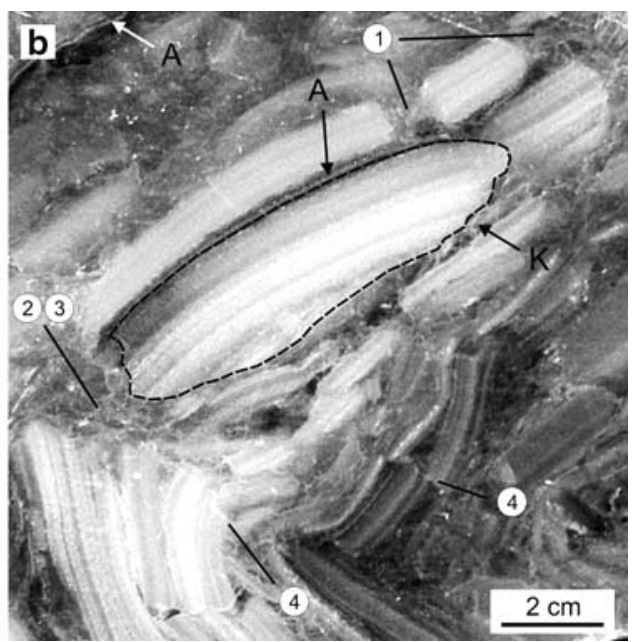

the central part (outlined by dashed line) has a thickness of $\sim 2.5 \mathrm{~cm}$ and a length of $\sim 9 \mathrm{~cm}$, and is overlain by a thin, massive anhydrite layer $(A)$. The lamination of this Kristallbrocken is well developed. According to the lamination, the original continuous layer can be visually reconstructed. Within the Kristallbrocken, there are no macroscopically visible grain boundaries. The grain boundary areas of the Kristallbrocken are partially rounded due to recrystallisation and/or dissolution processes. This example well documents the concurrent brittle and ductile deformation

They are mostly arranged in layers, and these layers are, like in Fig. 1, also affected by folding of the rock salt sequences, with the individual Kristallbrocken having been moved against each other or rotated. In more intensely deformed Stassfurt rock salts, e.g. in the salt structures of Morsleben or Gorleben (Bornemann 1991; Behlau and Mingerzahn 2001), rectangular to oval-shaped Kristallbrocken occur relatively isolated from each other, being embedded in a fluid inclusion-poor halite matrix (e.g. Bornemann et al. 2000; Pape et al. 2002). Simon (1972) regarded the Kristallbrocken as relics of formerly continuous crystal layers, which formed either by dissolution of parts of the crystal layers or by breaking apart of these layers during folding. He suggested that the occurrence of the Kristallbrocken layers in areas that are less subjected to deformation argues for dissolution of crystal layers as reason for their formation. However, in domal salt deposits, it is difficult to reconstruct the development of the Kristallbrocken layers during salt migration-related processes as well as their formation and deformation mechanisms, because the original sedimentary fabric has been largely destroyed. Bedded or less intensely deformed salt deposits with well-preserved Kristallbrocken are almost not accessible. But drilling for hydrocarbon storage caverns in the salt deposit Teutschenthal (Fig. 2) exposed less intensely deformed Stassfurt rock salt, in which the original sedimentary fabric, namely a rhythmic bedding of rock salt sequences and continuous anhydrite layers, has 
Fig. 2 a Map of Europe with an outline of the Late Permian Zechstein Basin (modified from Taylor 1998). b Sketch map of this basin showing the studied location Teutschenthal
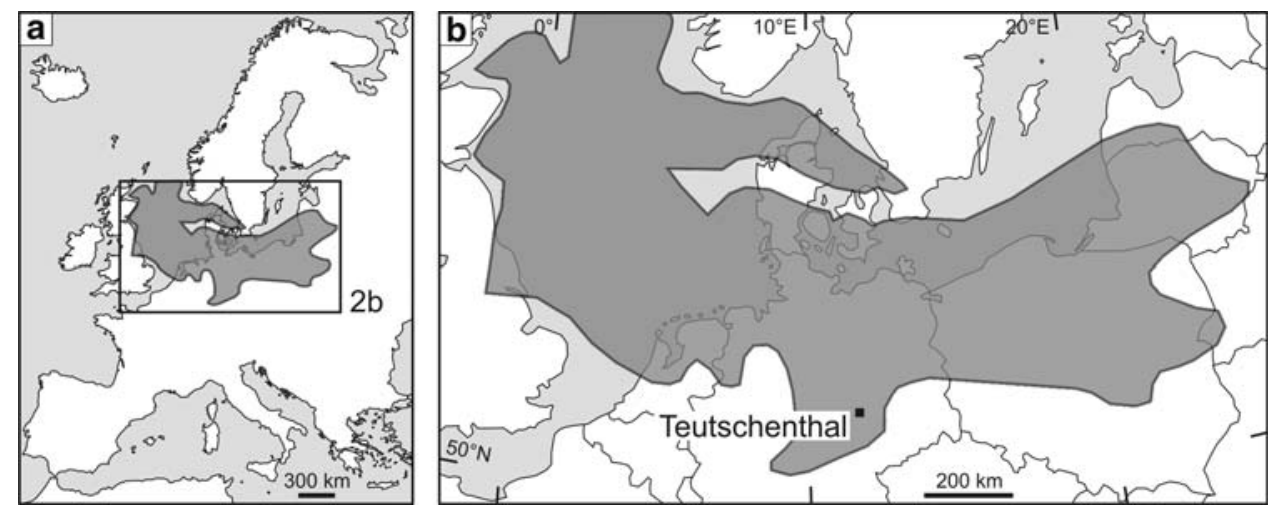

largely been preserved and the deformation characteristics of the Kristallbrocken layers are especially well observable. For example, these drilling cores show that the deformational behaviour of the Kristallbrocken ranges from brittle to ductile, and due to their internal lamination, the development of them can be visually reconstructed, which provides insights into the deformation mechanisms of the Kristallbrocken. The access to these drilling cores in the drill core storage facility of the Federal Institute for Geosciences and Natural Resources (BGR) now allowed us to contribute new data to the characteristics of the Kristallbrocken for a better understanding of the development of the Kristallbrocken fabric.

The aim of this study was to answer the following questions that arise from the above outlined observations: (1) Are the Kristallbrocken relics of very fine-grained, polycrystalline halite beds or clasts of 'single crystal-layers', or can they be regarded as postdeformational blasts? (2) When and how did they form and deform? For this purpose, we investigated the deformational characteristics of the Kristallbrocken based on samples from the salt deposit Teutschenthal and determined their local crystallographic preferred orientations $(\mathrm{CPOs}=$ textures $)$ by $\mathrm{X}$-ray texture goniometry. The better understanding of the texture of this halite fabric type may help us elucidating the deformation mechanisms that explain the observed microstructures.

\section{Geological setting}

The Zechstein Basin extended from Eastern England and the Southern North Sea in the west to Poland and Lithuania in the east (Fig. 2). During the Late Permian (Zechstein), the basin was repeatedly transgressed by seawater coming from the Arctic Sea. The cyclicity of these marine transgressions was presumably caused by glacio-eustatic fluctuations in sea level as well as tectonic processes (e.g. Smith 1979; Ziegler 1981, 1990; Taylor 1998). The high evaporation rates due to the arid climate conditions during

\begin{tabular}{|c|c|c|c|c|c|c|}
\hline \multicolumn{2}{|c|}{$\begin{array}{c}\text { Chrono- } \\
\text { stratigraphy }\end{array}$} & \multicolumn{3}{|c|}{ Lithostratigraphy } & \multirow{2}{*}{\multicolumn{2}{|c|}{$\begin{array}{c}\text { Lithostratigraphy } \\
\text { Lithology }\end{array}$}} \\
\hline Period & Epoch & Group & Formation & Symbol & & \\
\hline \multirow[t]{2}{*}{ 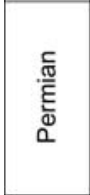 } & \multirow{2}{*}{ 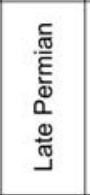 } & \multirow[t]{2}{*}{$\begin{array}{l}\frac{c}{\mathrm{~d}} \\
\stackrel{5}{0} \\
\frac{5}{0} \\
\text { N }\end{array}$} & \begin{tabular}{|c|} 
Fulda \\
Friesland \\
Ohre \\
Aller \\
Leine \\
\end{tabular} & $\begin{array}{l}\mathrm{Z} 7 \\
\mathrm{Z} 6 \\
\mathrm{Z} 5 \\
\mathrm{Z4} \\
\mathrm{Z} 3\end{array}$ & \multirow{2}{*}{\begin{tabular}{|c|}
$\begin{array}{c}\text { claystone } \\
\text { anhydrite } \\
\text { potash salts }\end{array}$ \\
rock salt \\
anhydrite \\
carbonate \\
claystone
\end{tabular}} & \begin{tabular}{|c|} 
Hangendsalz \\
Hauptsalz \\
Basissalz \\
\end{tabular} \\
\hline & & & \begin{tabular}{|c|} 
Stassfurt \\
Werra \\
\end{tabular} & $\begin{array}{l}\mathrm{Z2} \\
\mathrm{Z1}\end{array}$ & & \\
\hline
\end{tabular}

Fig. 3 Stratigraphic table of the German Zechstein group (adapted from Richter-Bernburg 1955; Käding 1978, 2000)

the Zechstein, combined with cyclic restriction of seawater influx into the basins, resulted in the deposition of the Zechstein carbonates and evaporites.

In Germany, the Zechstein group comprises four main evaporation cycles referred to as the Werra (Z1), Stassfurt (Z2), Leine (Z3), and Aller (Z4) formations (RichterBernburg 1955) and three rudimentary and only regionally occurring cycles referred to as the Ohre (Z5), Friesland (Z6), and Fulda (Z7) formations (Käding 1978, 2000) (Fig. 3). Each cycle is characteristic for a progressive evaporation phase, starting with clastic sediments like mudstones and followed by carbonates, anhydrites, rock salt, and potash salts. Today, Zechstein sediments occur in both flat-lying, apparently undisturbed settings, as well as in diapiric structures formed by salt tectonics (e.g. Trusheim 1960; Jaritz 1973; Kockel 1998).

\section{Samples and methods}

The samples investigated in this study belong to the Hauptsalz (German: 'Hauptsalz' = main salt) of the Stassfurt Formation (Fig. 3) of the salt deposit Teutschenthal (Fig. 4), a NW-SE trending anticlinal structure located at the southern rim of the former Zechstein Basin and formed by the accumulation of salt migrating from adjacent areas. They were obtained from wells drilled for hydrocarbon storage caverns, in which the rock salt of the Stassfurt Formation reaches a total thickness of approximately 


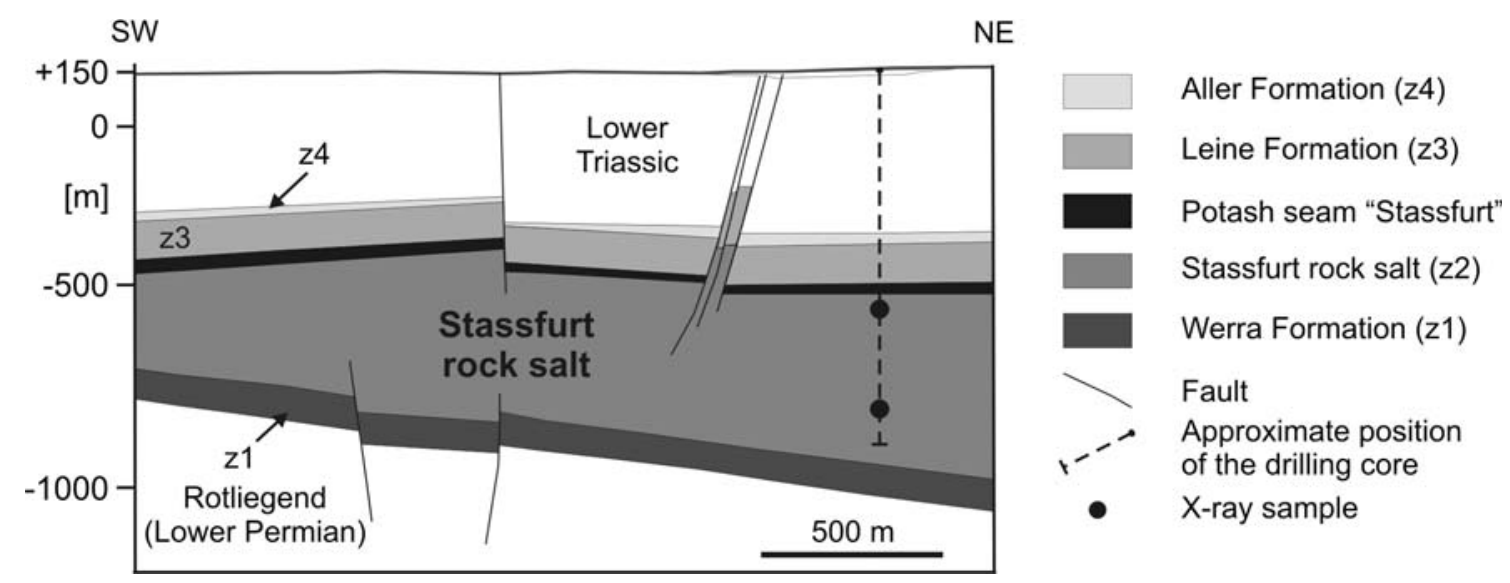

Fig. 4 Cross section of the flat-lying salt deposit Teutschenthal (modified from Jagsch and Theylich 1999) showing the approximate position of the drilling core. The samples for the X-ray texture analysis originate from depths of $\sim 940 \mathrm{~m}$ (Lt62-6-125) and $\sim 665 \mathrm{~m}$ (Lt60-12-89) below the surface
$480 \mathrm{~m}$. The original thickness of the Stassfurt Formation rock salt in this area is estimated to range between 300 and $400 \mathrm{~m}$, but due to salt migration, the present thickness varies considerably, with a maximum of about $1,000 \mathrm{~m}$ (Jagsch and Theylich 1999). The rock salt horizons are even bedded and largely undisturbed, consisting of layers with matrix halite and layers with the Kristallbrocken, and alternate with massive, continuous anhydrite layers.

For a macroscopical description of the Kristallbrocken, $1 \mathrm{~cm}$ thick drilling core (diameter $10 \mathrm{~cm}$ ) slabs cut parallel to the core axis were used. Samples were manually ground (dry) on a grinding instrument, using 60-, 120-, 500-, and 1000-grit $\mathrm{SiC}$ abrasive papers and polished with diamond spray $(3.0$ and $1.0 \mu \mathrm{m})$ on a low-napped synthetic cloth. Then, the surface of these slabs was wiped with a wet cloth in order to visualise the grains for reflected light photographs. The prepared slabs were studied by transmitted light using a Wild M3 stereomicroscope and photographed on a light table.

For microstructural investigations by reflected light microscopy, polished thick sections were etched with distilled water for $5 \mathrm{~s}$, then rinsed for some seconds with methanol, and finally dried in a jet of warm air. This procedure yielded optimal results in respect to the visualisation of grain boundaries and dislocation substructures within the grain. In view of electron backscatter diffraction (EBSD) analyses, other etching mediums were tested, including slightly undersaturated $\mathrm{NaCl}$ solution, $0.2 \mu \mathrm{m}$ water-free silica suspension, and diluted $\mathrm{HCl}$, with a mixture ratio of $\mathrm{H}_{2} \mathrm{O}: \mathrm{HCl}=5: 1$. However, the preparation of the Kristallbrocken was quite problematic because of the solid inclusions and the fluids that surround them. During polishing, the sulphate crystals fall off and scratch the sample surface, and the brine released during etching leads to minute halite crystals on the surface.

The two samples for X-ray texture analysis originate from depths of about $940 \mathrm{~m}$ (Lt62-6-125) and $665 \mathrm{~m}$ (Lt60-12-89) below the surface (Fig. 4). Generally, the Kristallbrocken of the Stassfurt rock salt of Teutschenthal consist of halite and anhydrite, with the latter estimated to range from about $1-5 \%$. For texture analysis, we prepared $1 \mathrm{~cm}$ thick sections from the drilling core slabs used for the macroscopic description of the Kristallbrocken. The sample sizes are $6 \mathrm{~cm} \times 3 \mathrm{~cm}$ (Lt62-6-125) and $7 \mathrm{~cm} \times 6 \mathrm{~cm}$ (Lt60-12-89). The Kristallbrocken in these sections are normally cut approximately perpendicular to their lamination and parallel to the core axis. The sample pieces were manually ground in order to get a planar surface and to remove new halite precipitates that result from slight etching of the sample surface by air moisture. Immediately before the measurements, the sample surface was cleaned with pure water and then quickly dried with a tissue. This was done in order to remove lattice defects of the uppermost surface that have potentially been induced mechanically by grinding. Besides, after the measurements, it was checked by reflected light microscopy if new crystals formed on the surface of the sample.

Texture measurements of the Kristallbrocken were carried out with conventional but modern X-ray texture goniometry: a poly-capillary glass fibre lens at the primary beam side provides high X-ray intensities and a large beam size of up to $7 \mathrm{~mm}$ for diffraction on the sample, a cross slit system in front of the poly-capillary lens allows varying beam sizes, and a computer-controlled sample movement allows automated measurements of series of local textures on a regular and irregular grid (Leiss 2005; Leiss and Ullemeyer 2006). The measurements were performed using 


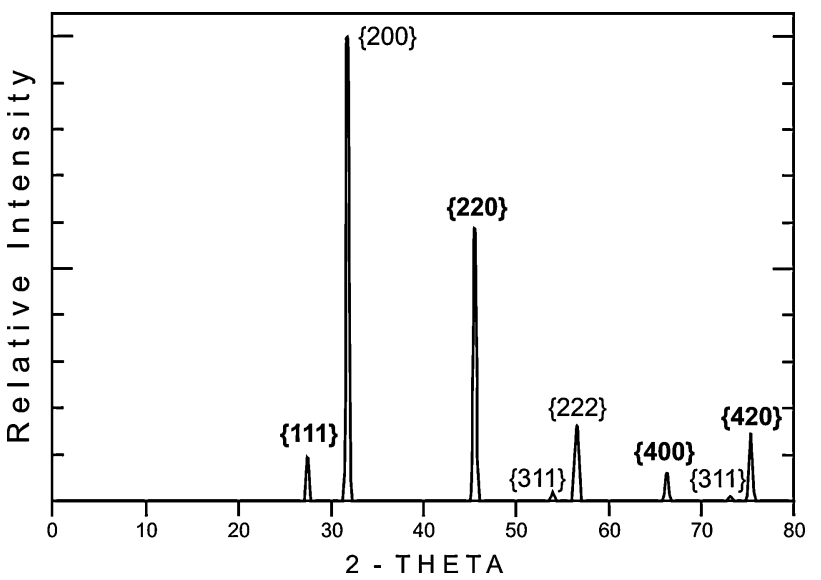

Fig. 5 Diffraction pattern of halite computed by means of Xpow (adapted from Downs et al. 1993). Pole figures were measured of reflections indicated in bold. For the basal planes, the intensities of the $\{400\}$ instead of the $\{200\}$ reflection was measured, because the high intensity of the $\{200\}$ reflection of the single crystal texture type could have destroyed the X-ray detector

a PANalytical X-ray texture measuring system (based on the company diffraction components PW-3040, PW3050/ 60, PW3060/20). A diffraction pattern of halite is presented in Fig. 5. For each sample, several positions for measuring locations were determined. A beam size of $2 \mathrm{~mm} \times 2 \mathrm{~mm}$, an anode current of $30 \mathrm{~mA}$, a voltage of $30 \mathrm{kV}$, and a measuring grid for the pole figures of $5^{\circ} \times 5^{\circ}$ was applied. From a sample rotation angle $\varphi=360^{\circ}$ and a tilting angle $\psi=85^{\circ}$, an incomplete pole figure measuring grid of 1,296 intensities resulted. For the rotation angle Phi, continuous measuring was applied to integrate the intensities between the grid points. The reflected intensities of the hklreflections $\{111\},\{220\},\{400\}$, and $\{420\}$ were measured. The resulting data were converted by means of the computer program XTexCor 1.0 (written by Ullemeyer in 2006). For pole figure presentations, we used the program PFPlot 2.2 (written by Umlauf and Ullemeyer in 2006). Pole figures are presented as equal area projections for the lower hemisphere. In the pole figures, the orientation is presented as multiples of a random distribution (m.r.d.). Lowest contour lines are equal to 1 and 5 m.r.d. and illustrated in grey; from 10 m.r.d., contour lines are illustrated in black, with a contour level distance of 20 m.r.d.

To check the crystallographic compatibility of the pole figures, the so-called texture component method was applied in a qualitative sense by means of the program MulTex 1.0 (e.g. Helming and Eschner 1990; Helming 1995). By this method, Gaussian-shaped texture components are fitted in the experimental pole figures, with each component representing a CPO locally restricted in the orientation space (see, e.g. Leiss et al. 1994; Leiss and Molli 2003 for descriptive applications of this method).

\section{Results}

Microstructural characteristics

Although the Teutschenthal anticline is a flat-lying salt deposit with largely undisturbed evaporite sequences, the Stassfurt Formation rock salt shows a set of microstructural features that suggest deformation-related processes and therefore documents the beginning of salt migration and accumulation. Such indicators can be observed in context with several Kristallbrocken, with matrix halite, and with anhydrite layers.

The most distinguishing feature of the Kristallbrocken in comparison to the halite matrix is that they show not only ductile, but also brittle deformational behaviour. For example, numerous Kristallbrocken could be observed in the Stassfurt Formation rock salt of Teutschenthal that were transected by sets of faults that caused relative displacement of the fragments (Fig. 6a, b). These faults do not continue into the halite matrix surrounding the Kristallbrocken. The individual fragments of the broken Kristallbrocken can be moved passively against each other and stacked (Fig. 6c, d), they can be rotated away from each other, or, less frequently, dragged apart (Fig. 6e, f). Such motions relative to each other can be well reconstructed due to the internal lamination of the Kristallbrocken. The Kristallbrocken are also subjected to ductile deformation, which can be observed in etched Kristallbrocken surfaces that show a network of subgrains under reflected light (Fig. $7 \mathrm{~g}$ ). Furthermore, some Kristallbrocken show areas in which the internal lamination has been destroyed and new grains (Fig. $6 \mathrm{~g}-\mathrm{i}$ ) were formed by recrystallisation, or possibly by microfracturing and subsequent healing by precipitation of halite. A special phenomenon is the occurrence of bent or even folded Kristallbrocken (Figs. 6j-1, 12), with observed interlimb angles ranging from $170^{\circ}$ up to $85^{\circ}$. The oval shape of many Kristallbrocken may be due to local recrystallisation or dissolution of the boundary areas. Some Kristallbrocken are bent and fractured. The arrangement of the microstructures indicate a beginning buckling of the Kristallbrocken layer, which is followed by fracturing, presumably when the stress cannot be accommodated by bending anymore (Fig. 6k, 1).

Individual fragments of the Kristallbrocken or layers containing large Kristallbrocken are mostly surrounded by the halite matrix that is composed of clear, partially elongated halite grains, with grain sizes ranging from 0.2 to $1 \mathrm{~cm}$ (Fig. 7a). These grains rarely show internal fluid or anhydrite inclusions, but exhibit worm-like fluid or gaseous inclusions in large quantities at their grain boundaries (Fig. 7b, c). In addition, individual anhydrite crystals or aggregates are often arranged at the grain boundaries of the 
Fig. 6 Drill core photographs of Stassfurt rock salt samples of the flat-lying salt deposit Teutschenthal showing the deformational characteristics of the Kristallbrocken. Arrow in white box indicates stratigraphic up direction (=core axis). In general, the rock salt horizons consist of well-laminated halite, the so-called Kristallbrocken $(K)$, and fluid inclusion-poor, middle- to coarse-grained matrix halite $(M)$, and alternate with thin, partly folded anhydrite layers $(A)$.

a, b Kristallbrocken transected by faults (1) that caused relative displacement of the fragments. $\mathbf{c}, \mathbf{d}$ The individual fragments of the broken Kristallbrocken were moved passively against each other and stacked (2). e Broken relics of a Kristallbrocken rotated away from each other. f Two Kristallbrocken pieces dragged apart. Thick section photograph in transmitted (g) and reflected light (h) showing a Kristallbrocken with new grains (3) in the middle part that do not show the internal lamination anymore. i Formerly bent Kristallbrocken with an internal lamination. In the curvature zone, new grains formed (3), with the internal lamination having been destroyed. j-l Thick section photographs showing slightly bent and folded Kristallbrocken
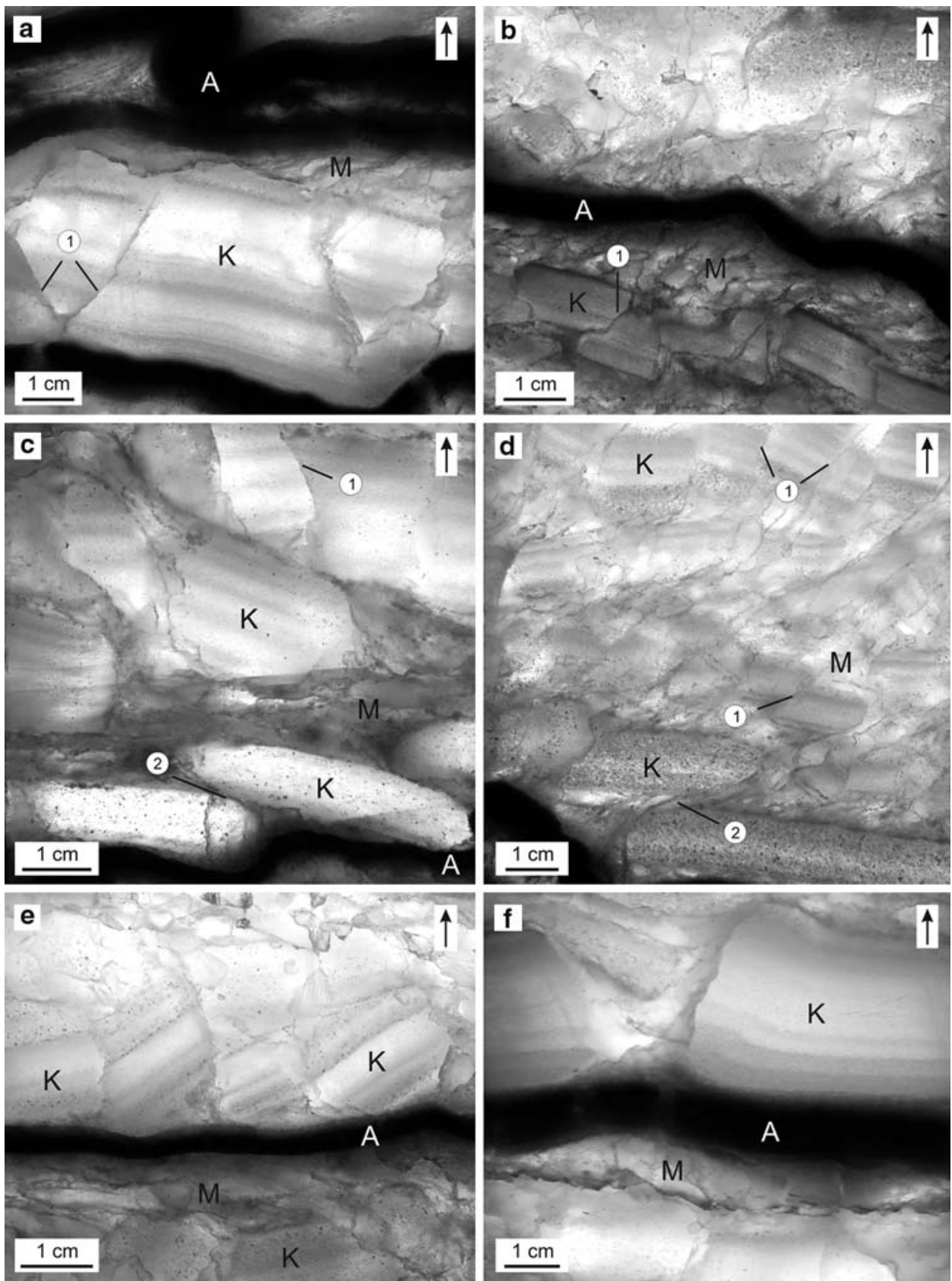

matrix halite (Fig. 7c, f). The presence of fluid inclusions at the grain boundaries suggests that the matrix halite has been largely recrystallised (Roedder 1984). Reflected light examination of etched sample surfaces revealed that the matrix halite contains both subgrain-free and subgrain-rich grains in different parts of the Hauptsalz (Fig. 7d-f). The sub-grain size distribution is rather heterogeneous, with sizes ranging between about 40 and $500 \mu \mathrm{m}$. Some boundaries of sub-grain-free grains show lobate shapes in relation to sub-grain-rich grains (Fig. 7d) indicating the direction of the migrating boundary (Urai et al. 1986; Passchier and Trouw 1998). During such grain boundary migration recrystallisation, highly sub-structured grains are consumed by less sub-structured grains. In some areas of the rock salt, strain shadows consisting of very fine-grained matrix halite formed in the hinge domains of folded anhydrite layers (Fig. 7h, i).

The interbedded anhydrite layers are partially irregularly folded (Figs. 6a, 1, 7h, i) or boudinaged, which results from deformation processes in consequence of the strong competence contrast between matrix halite and anhydrite layers. Partly, the anhydrite layers were subjected to recrystallisation of the halite yet, which can be seen by the finely dispersed anhydrite in the surrounding matrix halite. 
Fig. 6 continued
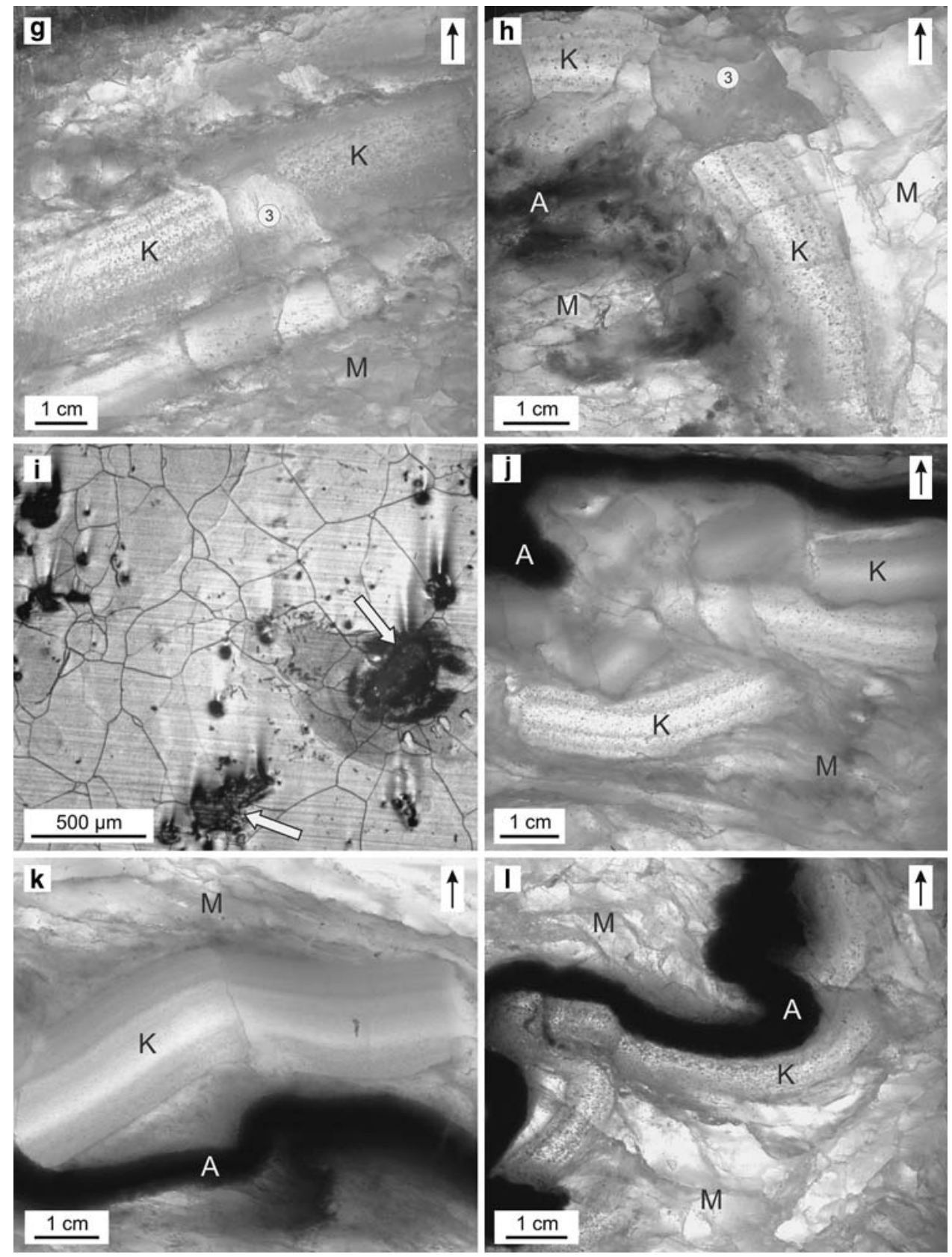

In comparison, in the Stassfurt rock salt of diapiric settings, anhydrite layers are mostly no continuous beds anymore, but largely occur as layer fragments or are finely dispersed in the rock salt (Fig. $7 \mathrm{j}, \mathrm{k})$.

\section{Texture analyses}

\section{Sample Lt62-6-125}

Figure 8a shows the sample Lt62-6-125 consisting of matrix halite and the Kristallbrocken. The investigated
Kristallbrocken (Fig. 8b) comprises two distinguishable Kristallbrocken pieces: a Kristallbrocken relict on the left side and one in the central part. The latter shows a healed fracture in the middle. The lamination is clearly visible and suggests that this Kristallbrocken was slightly bent before being fractured. The crystallographic orientation was measured at nine locations that are regularly distributed on the different Kristallbrocken areas (Fig. 8b). The experimental pole figures for the reflections $\{111\},\{220\},\{400\}$, and $\{420\}$ are presented in Fig. 9. 

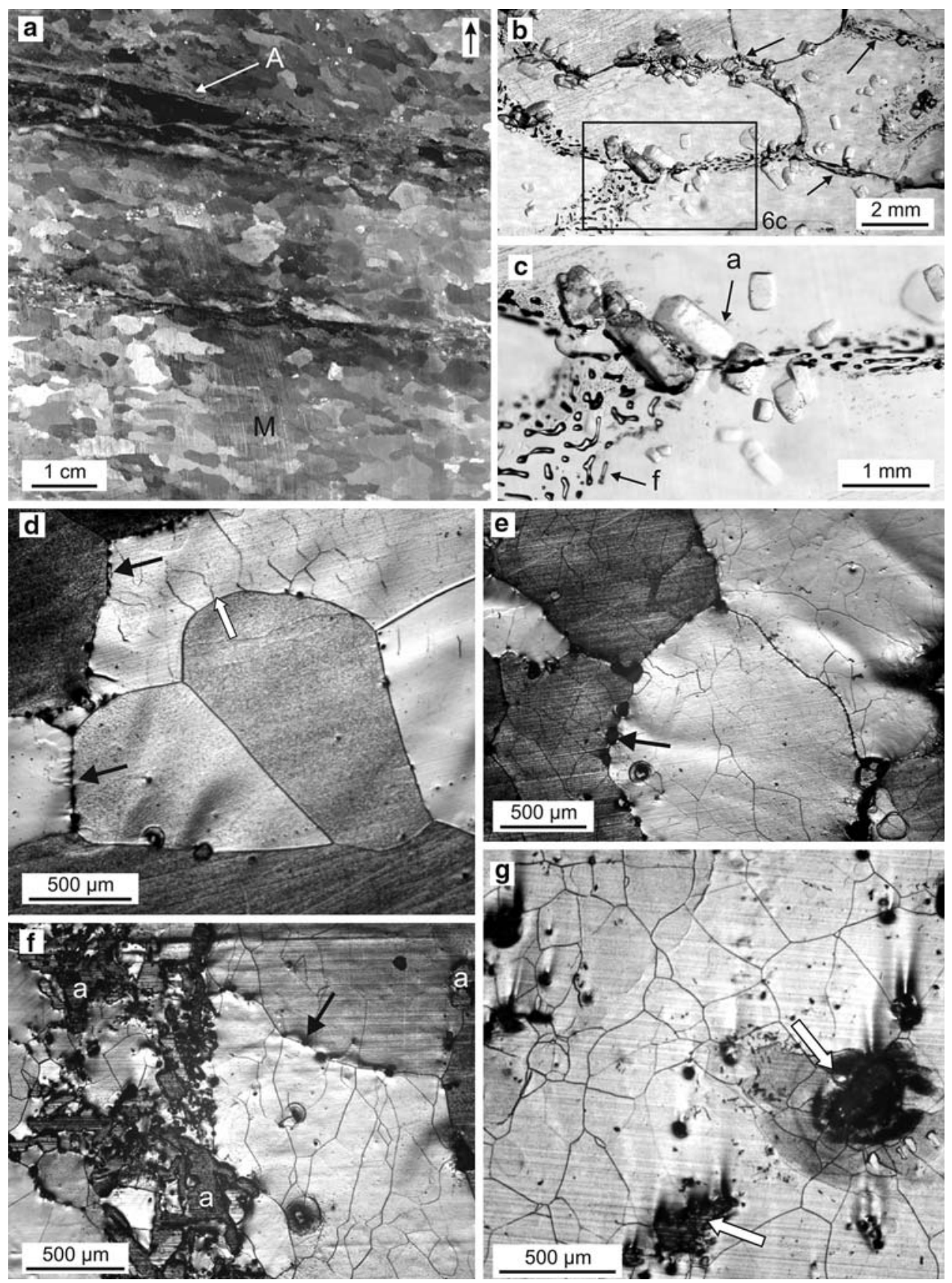

Fig. 7 a-i Photographs of Stassfurt rock salt samples of Teutschenthal. Arrow in white box indicates stratigraphic up direction (=core axis). a Drill core photograph (reflected light) showing the middle- to coarse-grained matrix halite $(M)$ alternating with very thin, massive anhydrite layers $(A)$. b Microphotograph (transmitted light) showing the relatively inclusion-poor matrix halite grains, with most fluid or gaseous inclusions as well as anhydrite crystals at their grain boundaries. c Scaled-up section of $\mathbf{b}$ showing arrays of worm-like fluid inclusions $(f)$ and anhydrite crystals $(a)$ at the grain boundaries. d-f Reflected light photomicrographs of etched halite matrix sample surfaces (from Küster et al. 2008). g Reflected light photomicrograph of an etched Kristallbrocken surface showing a network of subgrains. Thin dark lines are subgrain boundaries. Black spots represent former fluid or gaseous inclusions opened during the etching procedure. White arrows point to sulphate inclusions. h, i Drill core photographs (reflected light) showing strain shadows (dotted line) consisting of fine-grained matrix halite $(M)$ developed in the hinge domain of the folded anhydrite layers $(A) . \mathbf{j}, \mathbf{k}$ Drill core photographs showing Stassfurt rock salt samples of the salt diapir Morsleben. Arrow in white box indicates stratigraphic up direction (=core axis). Note that anhydrite layers are mostly no continuous beds anymore, but largely occur as layer fragments or are finely dispersed in the rock salt 

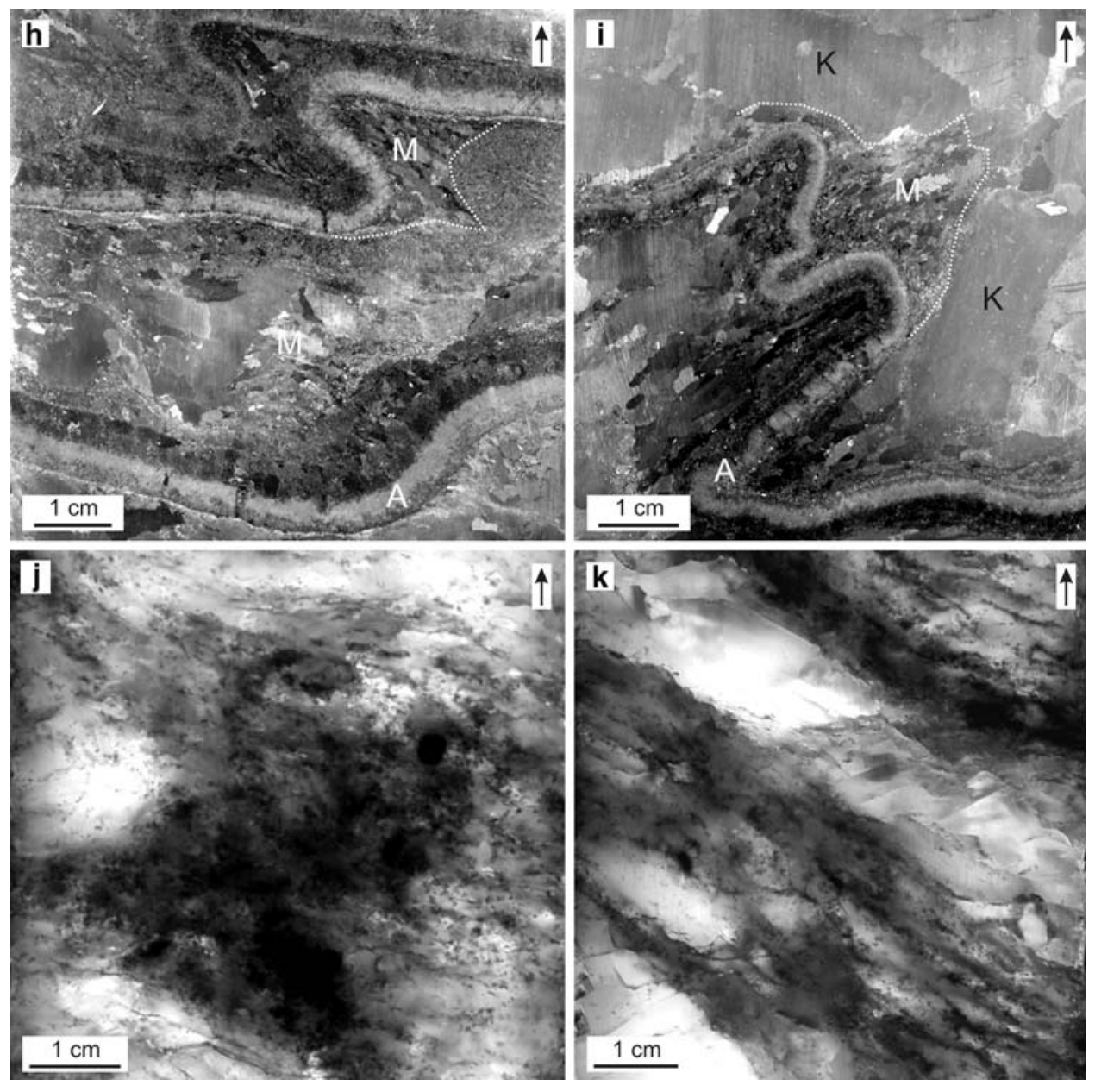

Fig. 7 continued

In all pole figures at all measuring locations, distinct, strongly developed intensity maxima can be observed. These clear and strong maxima can only result from a single crystal structure and not from a very fine-grained aggregate-structure of the Kristallbrocken. When comparing the results of the different Kristallbrocken areas, namely the pole figures of $\mathrm{P} 1$ and P2; P3, P4, P5, and P6; as well as $\mathrm{P} 7, \mathrm{P} 8$, and $\mathrm{P} 9$, the positions of the maxima are nearly identical for these areas (Fig. 9). This observation also supports the idea of the single crystal structure of the whole Kristallbrocken. When adding the pole figures of representative locations of neighbouring Kristallbrocken areas, namely $\mathrm{P} 1-\mathrm{P} 6$, or P3-P9, a relationship can be observed suggesting that the separated areas most likely originally formed one big undisturbed single crystal (Fig. 10). For example, the combined pole figures of P3-P6 and P7-P9 illustrate an angular difference of the crystallographic orientations between the two Kristallbrocken pieces of about $20^{\circ}$ around an axis normal to the pole figure projection plane. The relationship between the left and the middle Kristallbrocken area (P1-P2 and P3-P6; Fig. 10) is more complex. This is not the result of just a rotation around the bending axis but obviously also shows a tilting around an axis parallel to the pole figure projection plane.

By means of the texture component method, the compatibility of the experimental pole figures could be well demonstrated, especially in view of the maxima positions (Fig. 11, Table 1). The intensities of the maxima, however, are partly incompatible within and between the pole figures. This is mainly because of two experimental conditions: (1) the single crystal structure of the Kristallbrocken pieces causes very strong peaks, which cannot be quantitatively measured with a measuring grid of $5^{\circ} \times 5^{\circ}$ because the very sharp maximum intensities may be located between the grid points of the small circles associated to the tilt angle steps of $5^{\circ}$; (2) during pole figure measuring, the reflected X-ray intensities decrease due to defocusing beam geometry conditions at high tilt angles. A correction of the defocusing effect was not carried out since in this case of single crystals, it would be a complex 


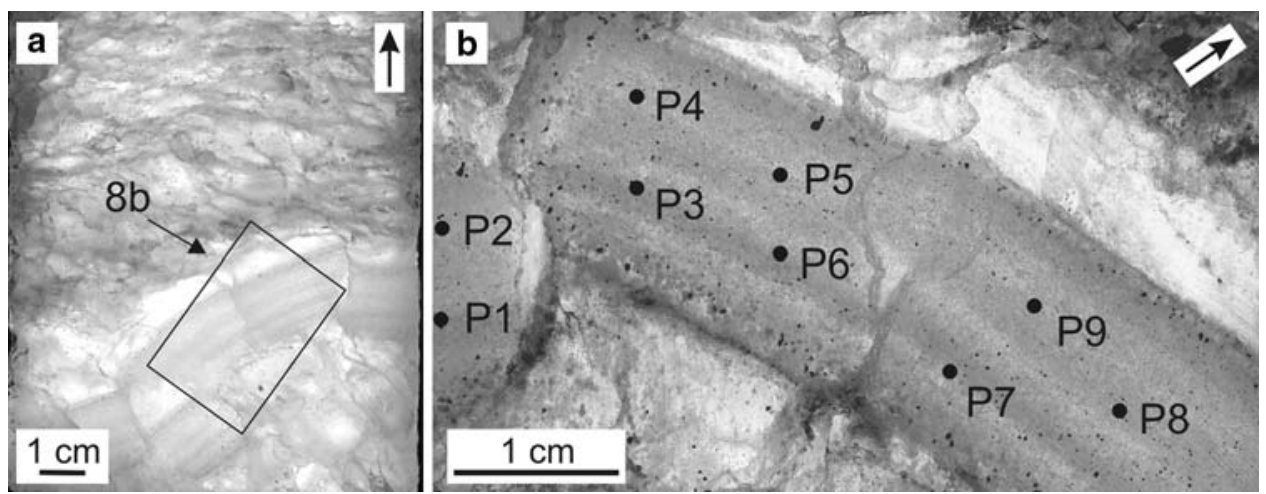

Fig. 8 a Thick section photograph of sample Lt62-6-125 (Teutschenthal) showing the investigated Kristallbrocken. b Scaled-up section of a showing the nine measuring locations for the X-ray

duty, especially in combination with point (1). Besides, such corrections would not help to understand this texture in a better way or give us more information in view of the Kristallbrocken formation. The main question, namely if the Kristallbrocken form a single crystal texture, can be clearly answered by the crystallographic compatibility of the sharp maxima.

\section{Sample Lt60-12-89}

Sample Lt60-12-89 (Fig. 12) contains a folded Kristallbrocken cut nearly perpendicular to the fold axis. The lamination of the Kristallbrocken is rather weak, with few, relatively large sulphate inclusions. The measuring locations P1-P12 were arranged along the fold profile, whereas P13 and P14 were located on a piece that was separated from the limb of the Kristallbrocken fold (Fig. 12). The experimental pole figures are presented in Fig. 13.

All pole figures reveal distinct intensity maxima, similar to sample Lt62-6-125, and therefore again indicate that the Kristallbrocken are single crystals. However, in this sample, the positions of the maxima in all pole figures and thus the orientation of the halite single crystal changes continuously from point $\mathrm{P} 1$ to $\mathrm{P} 12$ following the expected change of the folded Kristallbrocken structure. Besides, the pole figures of the hinge area show clear elongations of the maxima. These elongations are especially striking at the periphery of the pole figures indicating a bending of the crystal around a fold/rotation axis located close to the centre of the pole figure. A summary of all pole figures of the folded Kristallbrocken (P1-P12; Fig. 16) represents the bulk texture of the folded Kristallbrocken and more clearly visualises this observation. This also proves a fold/rotation axis with a direction near the centre of the pole figure.

Again, the texture component method was used to check the crystallographic compatibility of the measured pole figures. In the first instance, we checked this for the texture measurements. The Kristallbrocken is slightly bent, with a fracture in the middle part. Arrow in white box indicates stratigraphic up direction (=core axis)

measurement at P5 (Fig. 14). In principle, the single crystal texture type of the Kristallbrocken at one measuring type could be well described by various components (Fig. 14). In detail, however, especially in the experimental and recalculated $\{400\}$ pole figure, the elongations of the maxima could not be fully represented. This can again be explained by the defocusing effect. At higher tilt angles, the beam covers a larger measuring area due to a changed geometry of the beam, which is well illustrated in Fig. 15a. A larger measuring area means that a more folded area of the Kristallbrocken crystal lattice is captured and a stronger elongation of the maxima can be expected. In this context, it has to be considered that the characteristics of this effect additionally depend on the $2 \theta$ angle (Fig. 15a).

We also checked the crystallographic compatibility of the summarised pole figures of P1-P12 of Fig. 16. These summarised pole figures (Fig. 16) are an approach to represent the bulk texture of the bent Kristallbrocken structure with the advantage that some of the problematic effects of the pole figure compatibility are smoothed. Consequently, the bulk texture of the folded Kristallbrocken structure could be very well represented by ten components and therefore proves the plausibility of the measured data (Fig. 16, Table 1).

\section{Discussion}

An especially for rock samples configured X-ray texture goniometer was applied for the texture analysis of the rock salt type Kristallbrocken to analyse their internal structure to learn more about their development and deformation. This first study does not only prove the monocrystalline character of the Kristallbrocken, but also reveals experimental characteristics of this special application, which help to refine further methodical strategies for a more quantitative approach to the structural analysis of the 
Fig. 9 Experimental pole figures of the reflections $\{111\}$, $\{220\},\{400\}$, and $\{420\}$ of the measuring locations on sample Lt62-6-125 (Fig. 8). Lowest contour lines (grey) are equal to 1 and 5 multiples of random distribution (m.r.d.). From contour line 10 m.r.d. (black), the contour interval is 20 m.r.d. Note that all pole figures show strongly developed maxima.

The positions of the maxima are nearly identical in the pole figures of P1 and P2; P3, P4, $\mathrm{P} 5$, and P6; as well as P7, P8, and $\mathrm{P} 9$
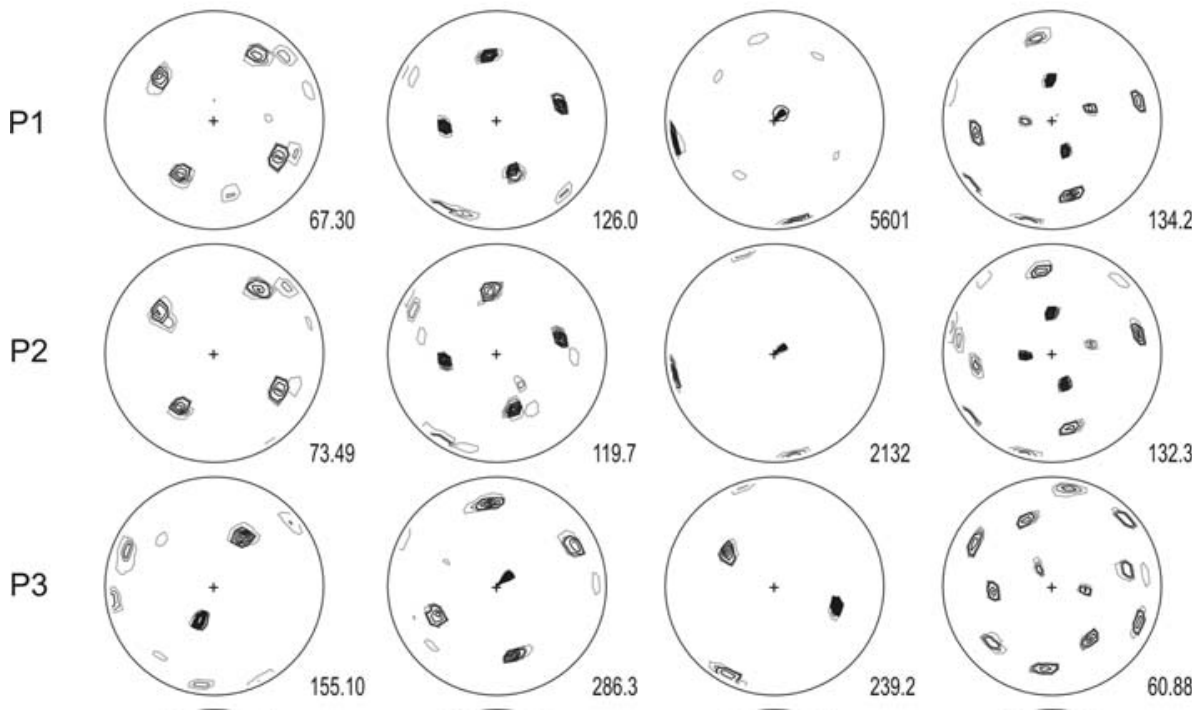

P4
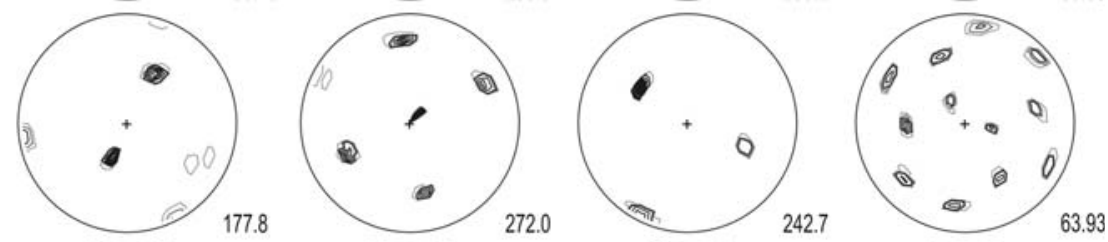

P5
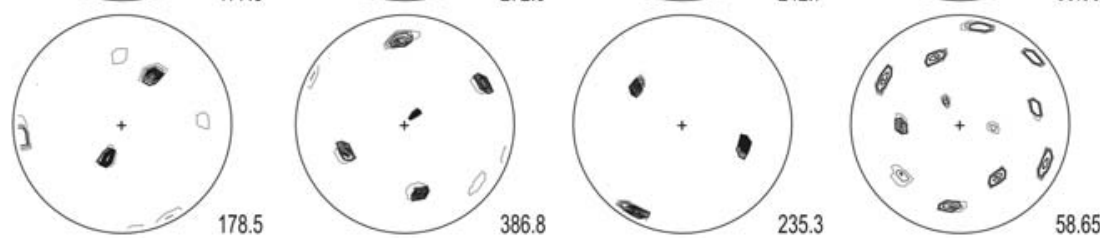

P6
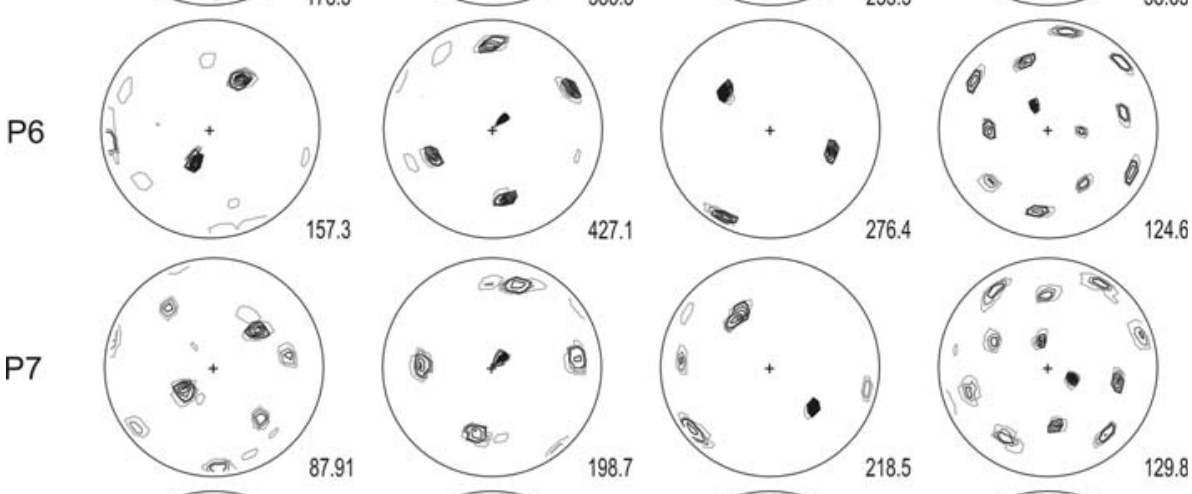

P8
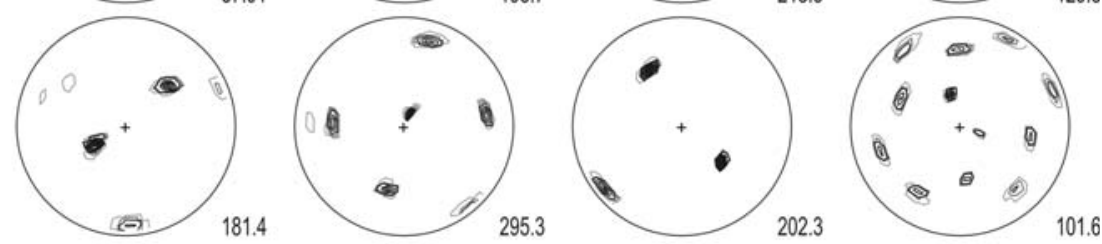

P9
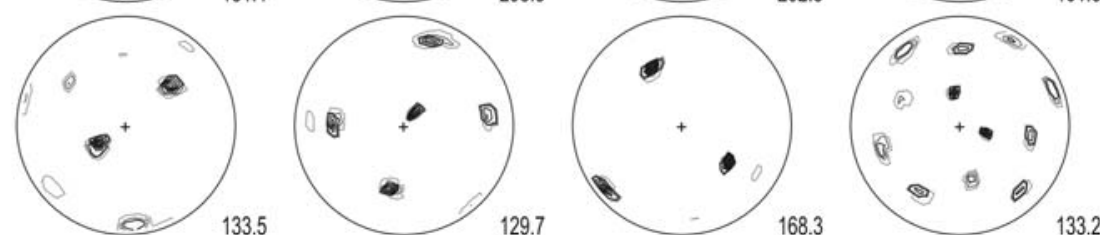


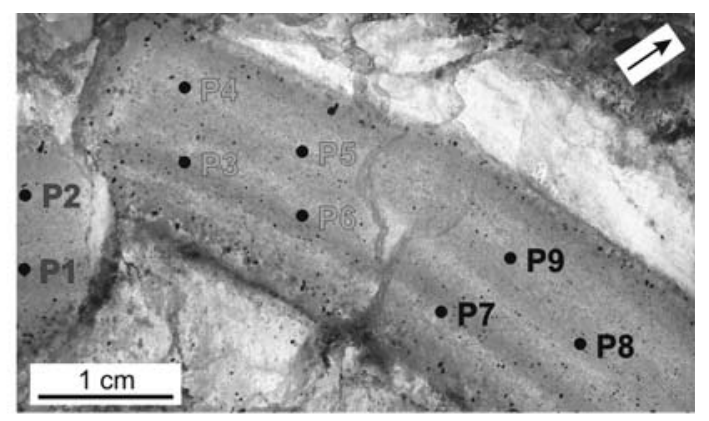

$\{111\}$

$\{220\}$

$\{400\}$

$\{420\}$
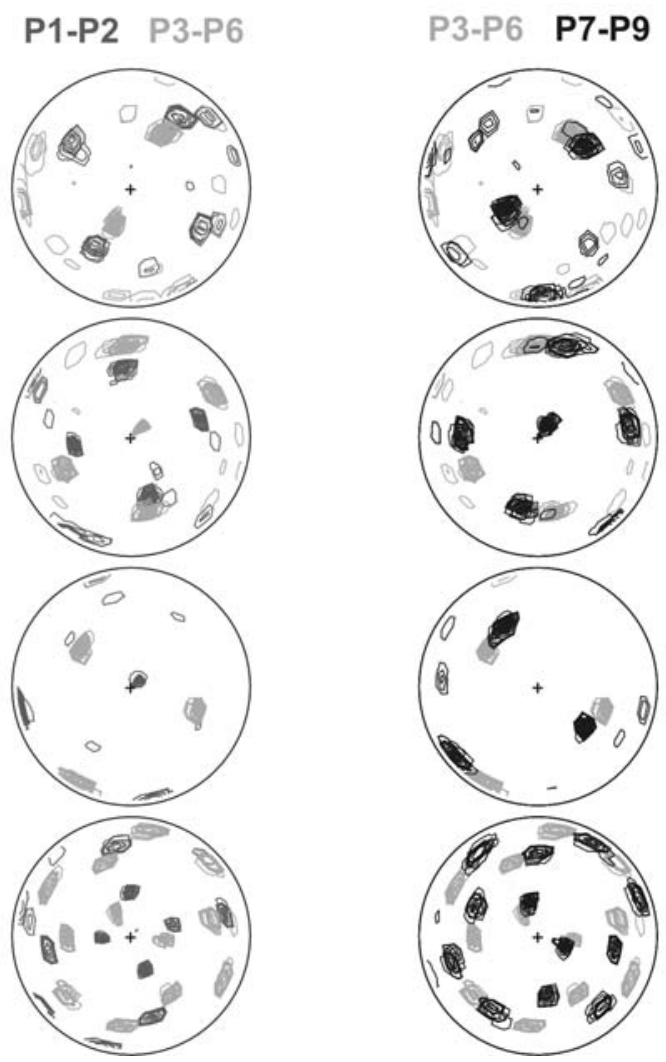

Fig. 10 Added pole figures of the reflections $\{111\},\{220\},\{400\}$, and $\{420\}$ of the measuring locations P1-P6 and P3-P9 of sample Lt62-6-125 (Fig. 8). For comparison, the contour lines are coloured in dark-grey for P1-P2, in light-grey for P3-P6, and in black for P7-P9. Arrow in white box indicates stratigraphic up direction

Kristallbrocken. These methodical aspects as well as the consequences of the monocrystalline character of the Kristallbrocken for the understanding of the Kristallbrocken formation and their subsequent deformation will be discussed in the following.

Texture analyses-methodical aspects

The results of the local X-ray texture measurements revealed that the neighbouring Kristallbrocken areas of sample Lt62-6-125 are monocrystalline and that these three separated pieces formerly formed one single monocrystalline Kristallbrocken. However, the single crystal structure of the Kristallbrocken is not perfect, which is obvious from the partially elongated maxima indicating that the single crystal pieces are weakly bent. This becomes much more obvious from the results of sample Lt60-12-89. While the local X-ray texture measurements of this folded Kristallbrocken again demonstrate the monocrystalline structure of the Kristallbrocken, the summarised local texture measurements, i.e. the bulk texture of this Kristallbrocken, clearly illustrate that this monocrystalline structure was bent or folded as a whole. The Kristallbrocken is neither internally recrystallised nor was it folded as a fine-grained polycrystal.

For the aim of this study, this general result is sufficient to draw conclusions on the formation and the deformation of the Kristallbrocken. Furthermore, the results demonstrate that the presented X-ray texture goniometer configuration is suitable to analyse such monocrystalline structures in a quick and efficient way. All this holds true for a general approach to the crystallographic analysis of the Kristallbrocken structure. A more detailed analysis of the results, however, shows some minor incompatibilities of the resulting pole figures, which make a more refined (i.e. quantitative) approach difficult. From the results, the following experimental conditions can be discussed to be responsible for the minor incompatibilities of the pole figures (compare with Fig. 15):

(1) The diffracted X-ray beam becomes defocused at large tilt angles, which leads to a decrease of the measured intensity towards the pole figure edge.

(2) A beam defocus is also associated with a changing geometry of the beam, i.e. the actually circular beam becomes an ellipse with increasing tilt angles (Fig. 15a). Consequently, the area of exposure on the sample surface changes as a function of the tilt angle.

(3) The shape and orientation of the beam and thus the area of exposure on the sample surface also changes as a function of the $2 \theta$ angle of the different pole figure reflection (Fig. 15a).

(4) The absolute maxima and positions of the strong peaks of these single crystal structures cannot always be exactly measured due to the applied relative rough measuring grid of $5^{\circ} \times 5^{\circ}$.

(5) Additional minor effects can be induced by the sample rotation in the area of the fold hinge. In the position of the fold axial plane parallel to the beam, a less strongly bent area is covered than in the position of the fold axial plane normal to the beam (Fig. 15b).

All these effects are related to each other. The correction would be very elaborate and complex. However, as already 
Fig. 11 a Experimental $(\exp )$ and recalculated $(\mathrm{rec})$ pole figures from the texture component model for the reflections $\{111\},\{220\},\{400\}$, and $\{420\}$ of P4 of sample Lt62-6-125 (Fig. 8). Lowest contour lines (grey) are equal to 1 and 5 m.r.d. From contour line 10 m.r.d. (black), the contour interval is 20 m.r.d. Note that the texture could be very well reproduced. b Orientation and relative intensity of the two main components that represent the single crystal texture of the Kristallbrocken

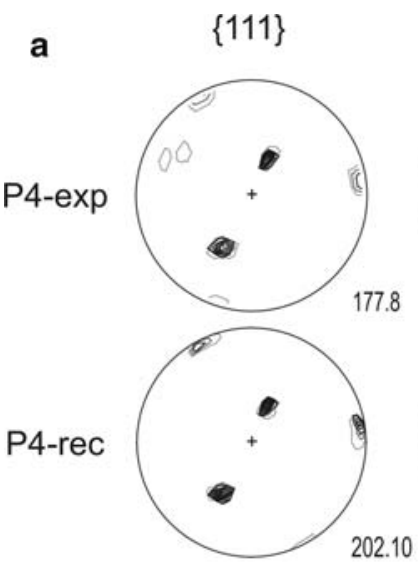

$\{220\}$

$\{400\}$

$\{420\}$
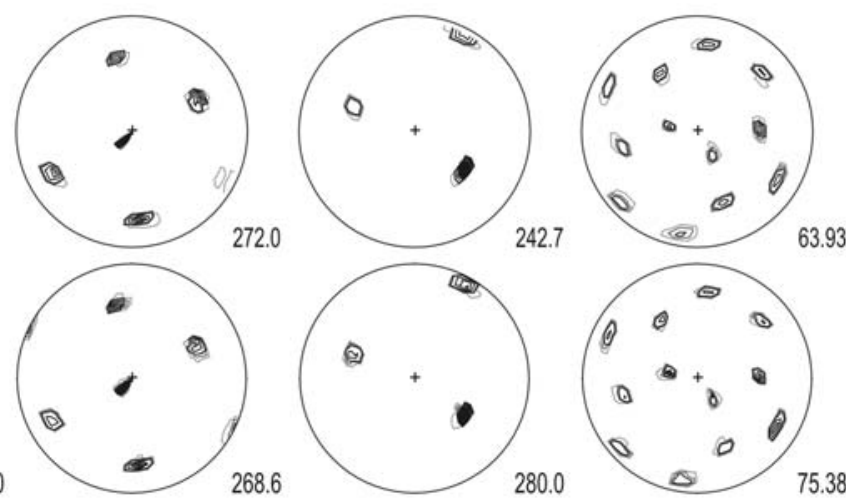

b

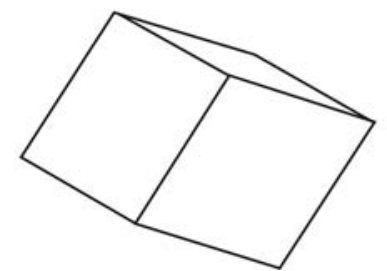

Component 2 Intensity: $20 \%$

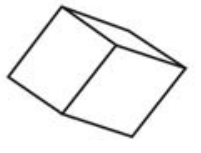

Table 1 Orientation, intensity and half width of the Gaussian-shaped texture components of the samples Lt62-6-125 and Lt60-12-89

\begin{tabular}{|c|c|c|c|c|c|c|}
\hline \multirow{2}{*}{$\begin{array}{l}\text { Sample } \\
\text { name }\end{array}$} & \multirow{2}{*}{$\begin{array}{l}\text { Number of } \\
\text { component }\end{array}$} & \multicolumn{3}{|c|}{ Orientation } & \multirow{2}{*}{$\begin{array}{l}\text { Intensity } \\
(\%)\end{array}$} & \multirow{2}{*}{$\begin{array}{l}\text { Half } \\
\text { width } \\
\left({ }^{\circ}\right)\end{array}$} \\
\hline & & $\alpha$ & $\beta$ & $\gamma$ & & \\
\hline \multirow[t]{2}{*}{ Lt62-6-125 } & 1 & 159.12 & 47.64 & 170.24 & 41.0 & 3.8 \\
\hline & 2 & 157.28 & 47.48 & 167.63 & 20.0 & 1.8 \\
\hline \multirow[t]{5}{*}{ Lt60-12-89 } & 1 & 240.96 & 50.39 & 167.84 & 11.8 & 4.1 \\
\hline & 2 & 258.12 & 51.41 & 164.14 & 11.4 & 4.7 \\
\hline & 3 & 301.76 & 62.07 & 163.95 & 18.8 & 6.1 \\
\hline & 4 & 292.56 & 57.90 & 162.93 & 10.7 & 4.8 \\
\hline & 7 & 280.48 & 55.12 & 161.75 & 11.9 & 7.1 \\
\hline
\end{tabular}

mentioned, in this study, a more quantitative approach would not help to improve the understanding of the crystallographic structure of the Kristallbrocken and therefore, we did not follow up the corrections. Anyway, in this case of single crystal structure analysis, the application of other techniques, for example the use of an area instead of a single detector, is much more promising for the future (e.g. Bunge and Klein 1996; Wcislak et al. 2002).

Texture analyses-microstructural aspects

Besides the above mentioned experimental aspects of producing minor incompatibilities of the pole figures, microstructural aspects might also be responsible:

(1) As it is shown in Fig. 7g, the microstructures of the Kristallbrocken show a regular mosaic of subgrains. They are responsible for a weak broadening of the

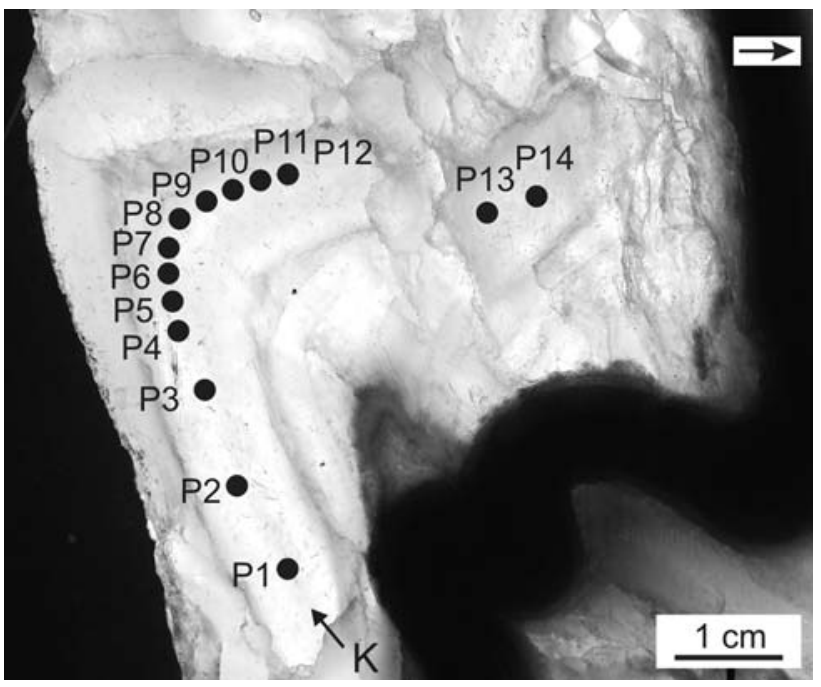

Fig. 12 Thick section photograph of sample Lt60-12-89 (Teutschenthal) showing the 14 measuring locations for X-ray texture measurements. The size of the drawn spots is equivalent to the beam width of about $2 \mathrm{~mm}$. The distance between the measuring locations $\mathrm{P} 4-\mathrm{P} 12$ is around $3 \mathrm{~mm}$ The Kristallbrocken $(K)$ is folded, with an interlimb angle of about $\sim 85^{\circ}$. Arrow in white box indicates stratigraphic up direction (=core axis)

maxima in the pole figures and, locally, can also be responsible for a slight deviation of the maxima elongation of the general structure. For a quantitative characterisation of these effects, we applied the EBSD technique on a scanning electron microscope (e.g. Prior et al. 1999; Trimby et al. 2000). However, due to major sample preparation problems, such characterisation was not possible. The numerous solid 
Fig. 13 Experimental pole figures for the reflections $\{111\}$, $\{220\},\{400\}$, and $\{420\}$ of the measuring locations on the folded Kristallbrocken of sample Lt60-12-89 (Fig. 12). Lowest contour lines (grey) are equal to 1 and 5 m.r.d. From contour line 10 m.r.d. (black), contour interval is 20 m.r.d.

Note that the position of the maxima in the pole figure and thus the crystallographic orientation changes continuously from point $\mathrm{P} 1$ to P12 following the fold structure. The Kristallbrocken piece that is separated from right limb of the fold has a clearly different crystallographic orientation (P13, P14)
$\{111\}$
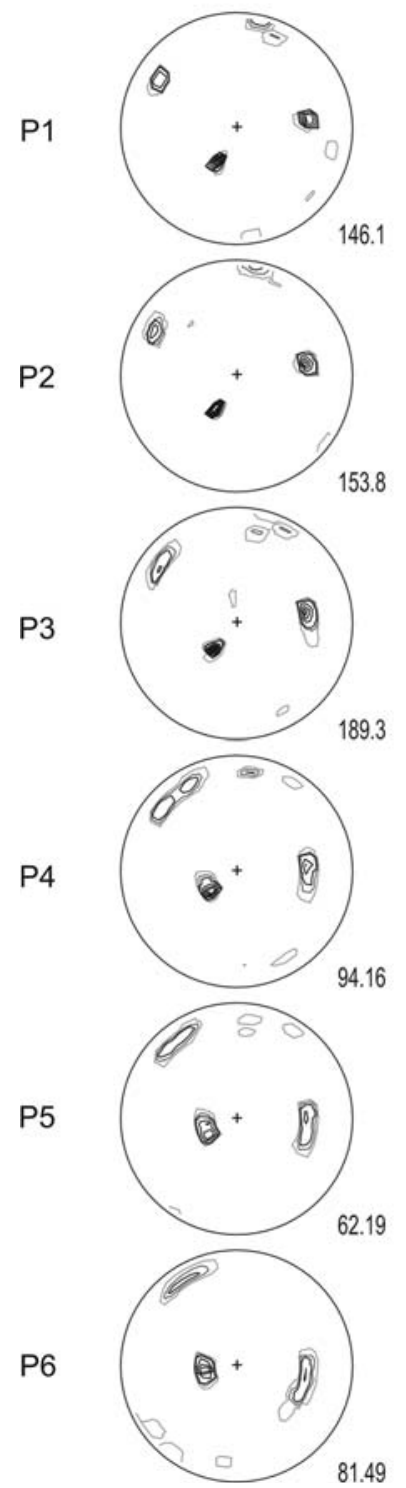

81.49
$\{220\}$
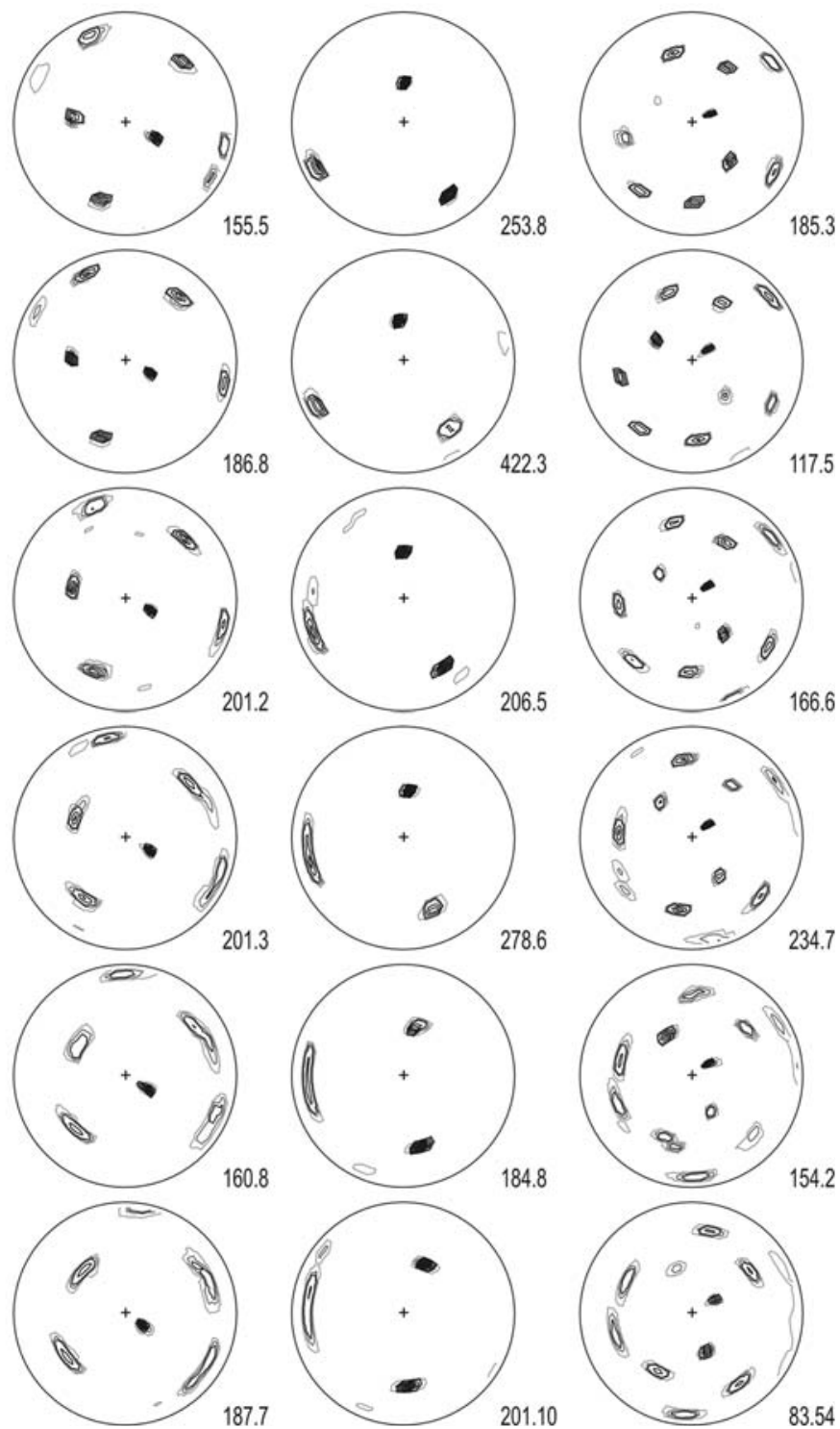

154.2

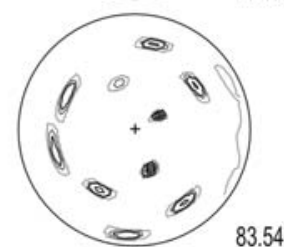

inclusions and fluids surrounding them (e.g. Fig. 7g) inhibited the preparation of a well measurable surface despite testing different polishing and etching techniques. Thus, it was not possible to analyse a statistically representative number of diffraction patterns within a regular measuring grid.

(2) As it will be discussed further below, it is difficult to exactly correlate the rotation/fold axis induced from the maxima elongations with a crystallographic direction of the ideal single crystal orientation. The reason might be the activation of a secondary slip system resulting from non-cylindrical folding. This effect can also result in apparent incompatibilities of the pole figures, but is too weak to be sufficiently resolved by texture components and/or would not be

distinguishable from the other error-inducing effects described above.

\section{Deformation mechanisms of Kristallbrocken}

The microstructural and textural investigations revealed that the Kristallbrocken show deformational characteristics ranging from brittle to ductile behaviour. Furthermore, the local X-ray texture measurements document the monocrystalline structure of the Kristallbrocken, as well as the monocrystalline structure of the bent Kristallbrocken. These findings help answering the questions how the Kristallbrocken deform, and what are the reasons for the basically different deformation mechanisms of the Kristallbrocken. 
Fig. 13 continued

$\{111\}$

$\{220\}$

$\{400\}$

$\{420\}$
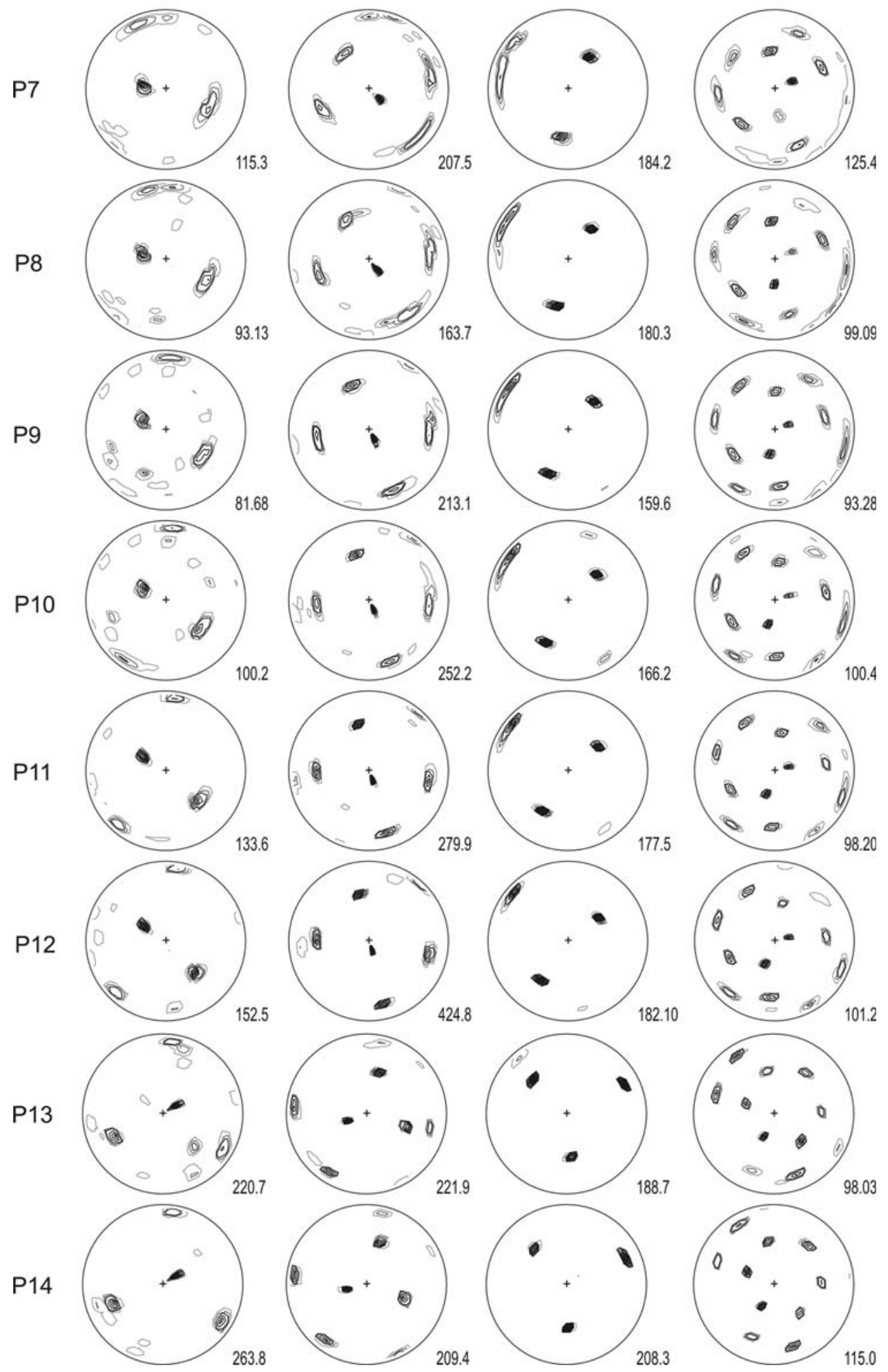

\section{Brittle deformation}

In general, the deformational behaviour of the Kristallbrocken appears to resemble that of porphyroclasts in

mylonitic rocks. This generally observed strong competence contrast between the Kristallbrocken and the finer-grained halite matrix can be explained by the monocrystallinity as well as the originally large size of the 'single 
Fig. 14 Experimental (exp) and recalculated $(\mathrm{rec}$ ) pole figures for the reflections $\{111\},\{220\}$, $\{400\}$, and $\{420\}$ of P5 of sample Lt60-12-89 (Fig. 12). Lowest contour lines (grey) are equal to 1 and 5 m.r.d. From contour line 10 m.r.d. (black), contour interval is 20 m.r.d. The single crystal texture could be basically reproduced. The reasons for some deviations mainly obvious in the $\{400\}$ pole figure are discussed in detail in the text
$\{111\}$

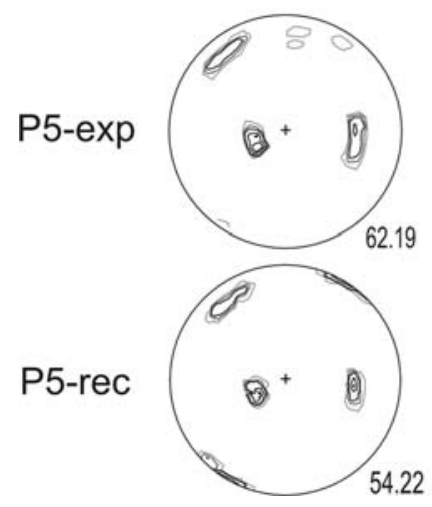

$\{220\}$

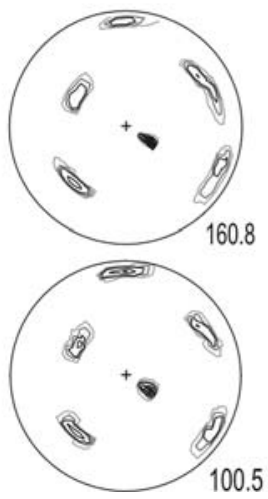

$\{400\}$

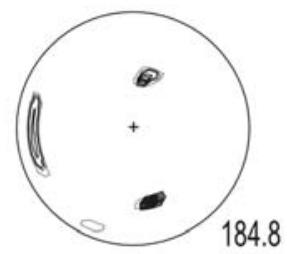

184.8

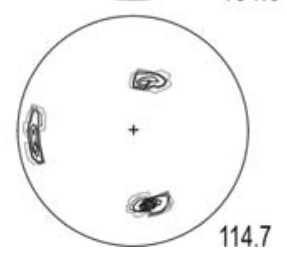

$\{420\}$
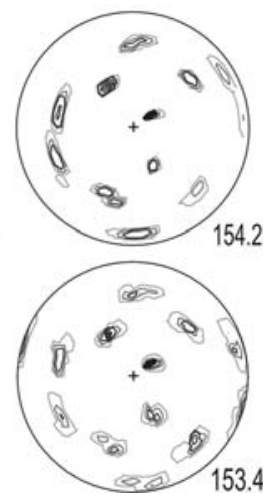

$$
\begin{aligned}
& a^{\left(90^{\circ}-\mathrm{x}\right)} \quad 0^{\circ} \quad 15^{\circ} \quad 30^{\circ} \quad 45^{\circ} \quad 60^{\circ} \quad 75^{\circ} \\
& 2 \theta=40^{\circ} \quad 0 \quad 000 / / \\
& 2 \theta=60^{\circ} \quad 0 \quad 000001
\end{aligned}
$$

Fig. 15 a Change in shape and orientation of the irradiated spot on the sample surface for different sample orientations as a function of tilt angle and Bragg angle 20. The incident beam is cylindrical with $2 \mathrm{~mm}$ diameter. Figure from Kocks et al. (1998). For comparison, the Bragg angles of the four reflections measured in this study are b

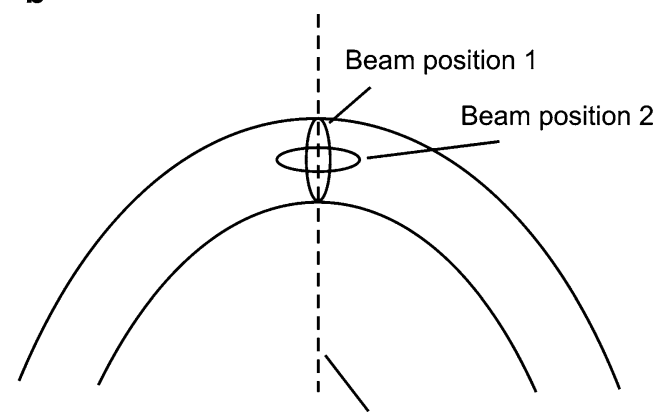

Fold axial plane
$2 \theta\{111\}=27.335^{\circ}, 2 \theta\{220\}=45.450^{\circ}, 2 \theta\{400\}=66.229^{\circ}$, and $2 \theta\{420\}=75.304^{\circ}$. b Changing texture due to changing measuring areas during sample rotation in the area of the fold hinge. In contrast to beam position 1 , in beam position 2 , an area with increased misorientation angle is covered crystal-layers' (see also discussion below). Additionally, the rigidity of the Kristallbrocken is expected to be further enhanced by the relatively large sulphate inclusions forming the internal lamination (Fig. $7 \mathrm{~g}$ ). It is a well-known problem in, e.g. foundry industry or metallurgy that cavities (e.g. shrinkage holes, blow holes) or brittle, nonmetallic inclusions can cause an embrittlement of steel or other solids (cf., Griffith 1924; Lawn and Wilshaw 1975). The presence of such inclusions leads to a restricted mobility of dislocations in the material, and, consequently, the Kristallbrocken basically accommodates the stress by brittle rather than by ductile deformation (Fig. 6a-f, k). With progressive deformation, however, a dynamic recrystallisation and/or solution-precipitation process starts at the boundaries of the Kristallbrocken leading to the typical core-mantle-structures (e.g. Fig. 1 and further deformed samples in the Hauptsalz from the Asse salt mine) and can probably end in completely recrystallised or dissolved Kristallbrocken.

\section{Ductile deformation}

Although the Kristallbrocken predominantly show brittle behaviour, they also show, apart from the already mentioned recrystallisation at the boundaries, a clear ductile behaviour by bending or folding (Figs. 6j-1, 12). These Kristallbrocken reveal substructures but no significant internal dynamic recrystallisation. This observation and the local texture analysis of the folded Kristallbrocken (Fig. 12) clearly documents that the crystal lattice as a more or less intact structure is bent. When adding the pole figures of P1-P12, the maxima in the resulting pole figures 
Fig. 16 a Added and recalculated pole figures of the reflections $\{111\},\{220\},\{400\}$, and $\{420\}$ of the measuring points P1-P12 of sample Lt6012-89 (Fig. 12; Teutschenthal). Lowest contour lines (grey) are equal to 1 and 5 m.r.d. From contour line 10 m.r.d. (black), contour interval is 20 m.r.d. Note that the elongation of the maxima along small circles $\left(\sim 75^{\circ}\right)$ approximately reflects the interlimb angle of the Kristallbrocken fold $\left(\sim 85^{\circ}\right.$; Fig. 12). b Orientation and relative intensity of the five components with highest intensity $(>10 \%)$ that represent the bulk texture of the folded Kristallbrocken

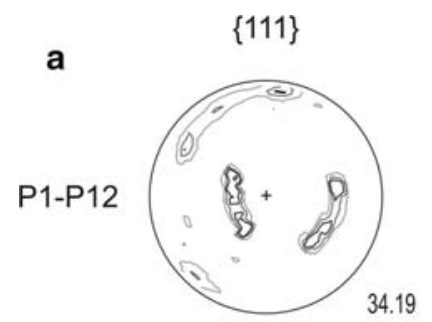

$\{220\}$

$\{400\}$

$\{420\}$
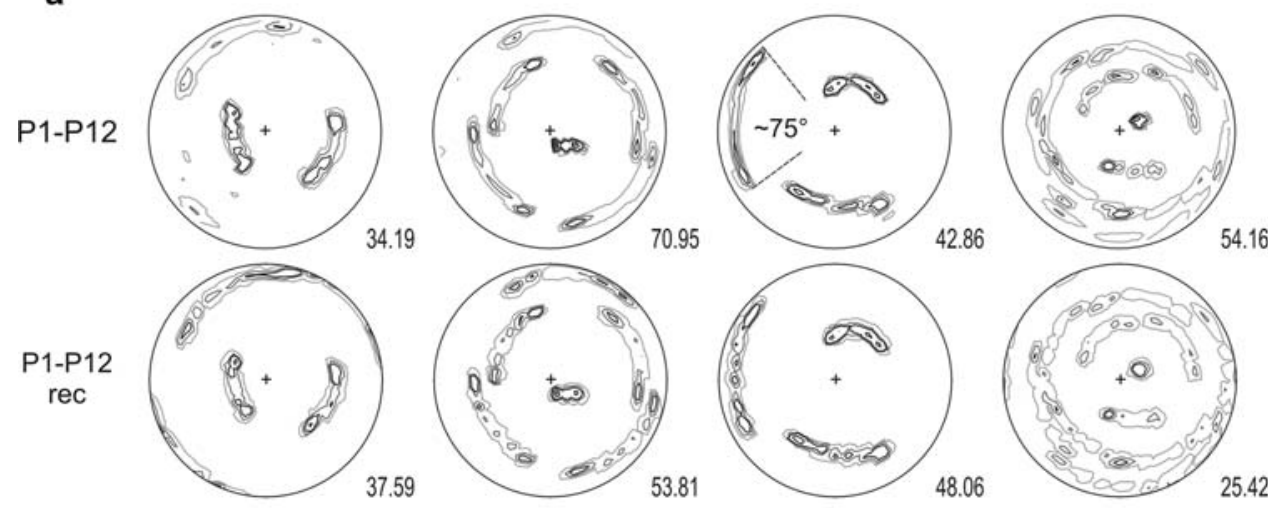

54.16

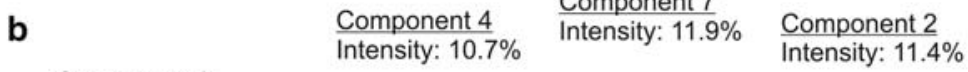

b $\quad \frac{\text { Component 4 }}{\text { Intensity: } 10.7 \%} \quad \frac{\text { Component } 7}{\text { Intensity: } 11.9 \%} \quad \begin{aligned} & \text { Component } 2 \\ & \text { Intensity: } 11.4 \%\end{aligned}$

Intensity: $18.8 \%$

Component 1

Intensity: $11.8 \%$

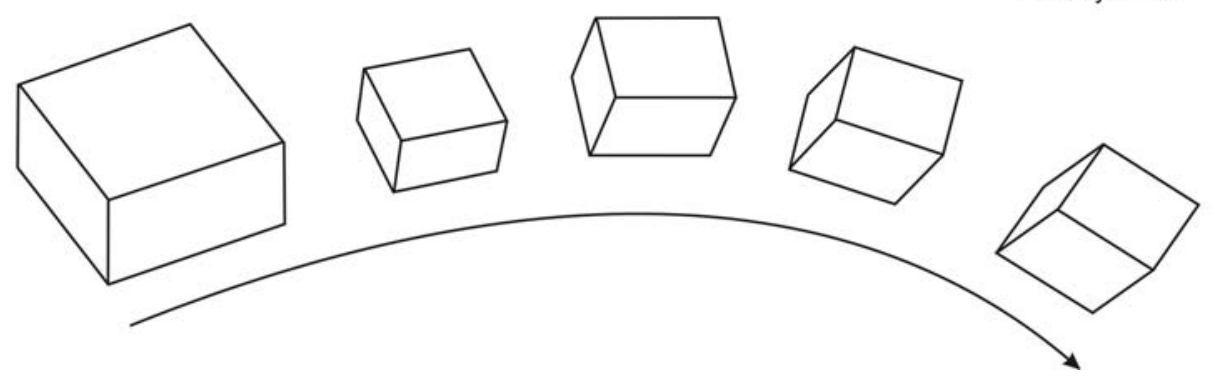

a

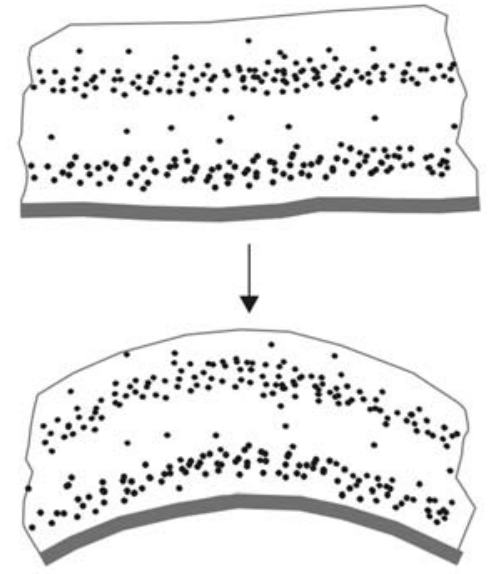

C
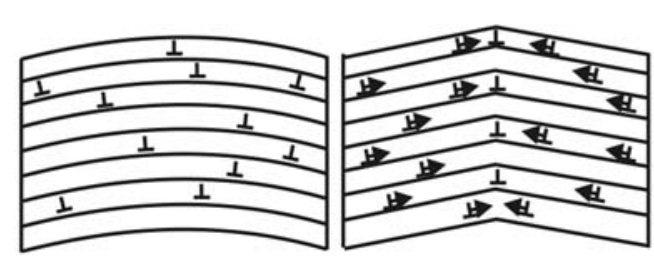

Fig. 17 The mechanisms for folding of the Kristallbrocken (a) is supposed to be flexural slip operating on crystallographic planes (b) by dislocation creep (c) (b, c from Twiss and Moores 1992). d The

b
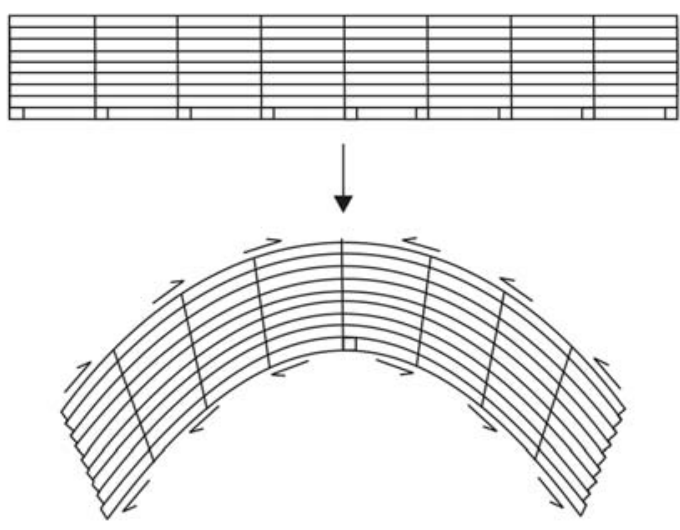

d
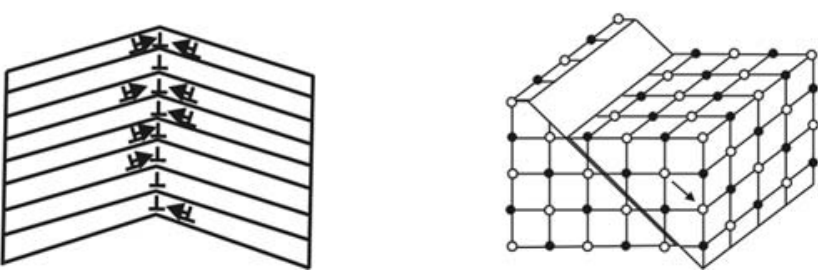

active slip system as it is deduced from the texture analysis (adapted from Scheffzük 1999) 


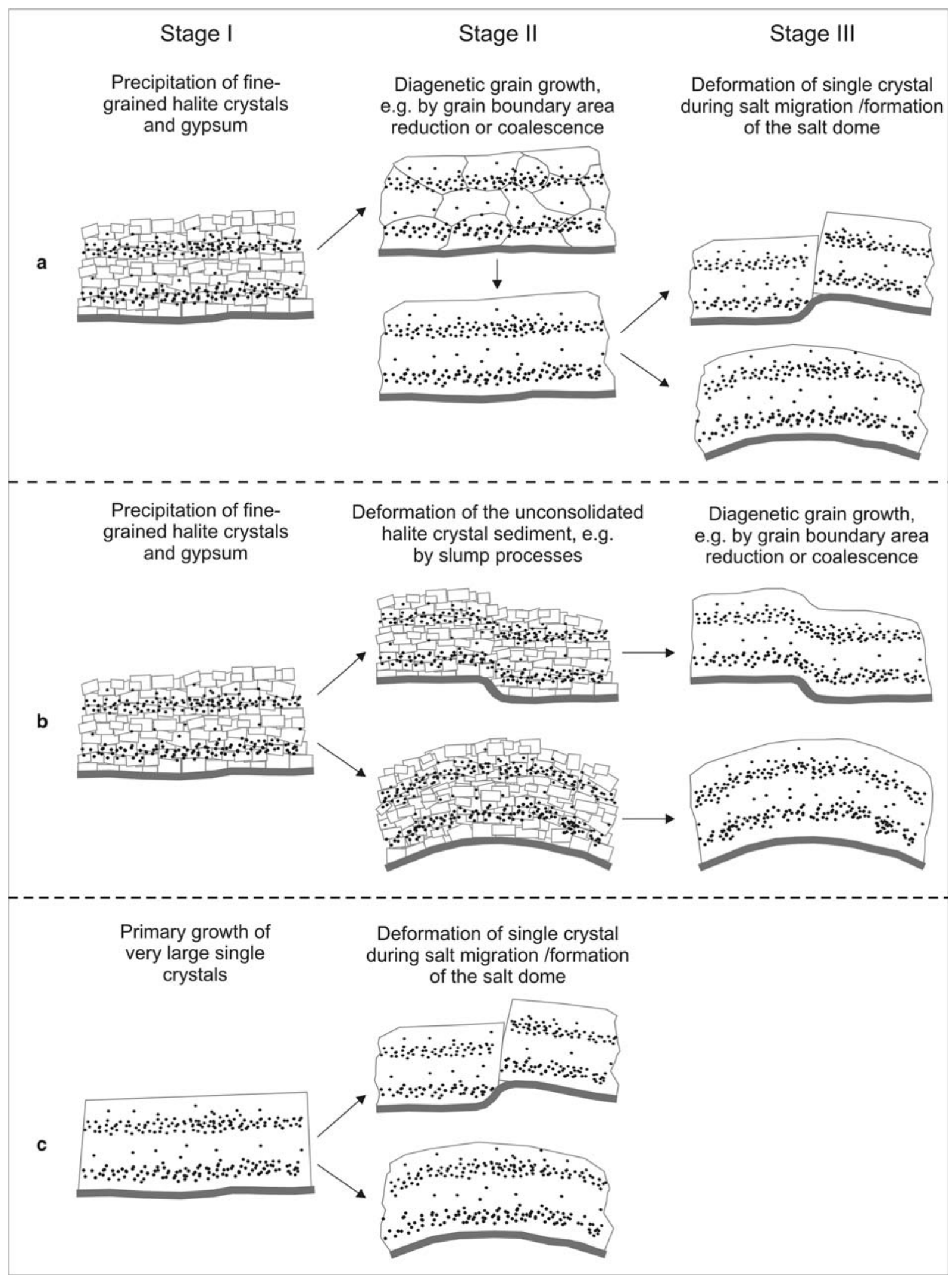

Fig. 18 Sketch with three models for the formation and development of the Kristallbrocken. Detailed explanations are given in the text 
are elongated along small circles (Fig. 16). The maximum elongation at the rim of the pole figure is about $75^{\circ}$ and approximately reflects the interlimb angle of the fold (Fig. 12). Two of the added pole figures have a maximum close to the centre; one is the $\{220\}$ and the other the $\{420\}$ pole figure. These maxima only show a weak or no elongation, so the fold/rotation axis is located near the centre of the pole figure, i.e. parallel or near the corresponding maxima of the $\{220\}$ or $\{420\}$ normal (Fig. 16). From these observations, a kind of flexural-shear folding (Fig. 17b; compare, e.g. with Twiss and Moores 1992) can be assumed as the deformation mechanism of the bent or folded Kristallbrocken (Fig. 17a). The lattice planes operate as shear planes. Intracrystalline slip on these lattice planes is enabled by dislocations (Fig. 17c) and the most probable slip system seems to be $\{110\}<110>$ (Fig. 17d). This conclusion is supported by the fact that this slip system shows the lowest critical resolved shear stress (CRSS) in halite at all temperatures (e.g. Carter and Heard 1970; Skrotzki and Haasen 1981; Skrotzki et al. 1981). However, the maxima near the centre of the added $\{220\}$ and $\{420\}$ pole figures are slightly distorted, suggesting that the orientation of the rotation axis changes across the fold. Consequently, the fold of sample Lt60-12-89 is probably slightly non-cylindrical or distorted. An additional slip system (compare, e.g. with Leiss and Barber 1999) cannot be inferred from the pole figure measurements because the elongation of the $\{220\}$ maximum close to the centre of the pole figure is only observed in the summarised pole figures (Fig. 16) and not in the pole figures of the single measuring spots (Fig. 13).

\section{Rheological specification of the Kristallbrocken}

The observed basic brittle deformational behaviour is different from that of granular salt, which is normally only known to be deformed in the ductile regime, i.e. without crack formation (e.g. Guillope and Poirier 1979; Carter and Hansen 1983; Carter et al. 1993; Hunsche and Schulze 1994), even at relatively high stress and low temperature conditions. Depending on the geological and tectonic setting, the strain rates for natural in situ deformation of rock salt range from $10^{-16}$ to $10^{-8} \mathrm{~s}^{-1}$ (e.g. Jackson and Talbot 1986; Watanabe and Peach 2002). According to Skrotzki (1984), for the formation of cracks in rock salt, short-term tectonic movements with strain rates higher than $10^{-11} \mathrm{~s}^{-1}$ have to be assumed, or the crack formation develops in weak zones like anhydrite-rich layers. However, due to the monocrystallinity, the large size, and the solid inclusions forming the internal lamination, the Kristallbrocken have clearly stronger rheological properties than fine- to coarse-grained polycrystalline salt, and thus also deform by fracturing.

Additionally, the orientation of the crystal lattice of the Kristallbrocken with respect to the stress field during the deformation plays an important role. As in this case bending or folding is most likely achieved by intracrystalline slip, the orientation of the crystal lattice with respect to the stress field is crucial for activation, because the CRSS are quite different for the different slip systems of rock salt (e.g. Carter and Heard 1970; Skrotzki and Haasen 1981; Skrotzki et al. 1981). The X-ray measurements have shown that the lamination of the Kristallbrocken is approximately parallel to the $\{220\}$ plane. The slip system $\{110\}<110>$ with the lowest CRSS for rock salt was already discussed as being responsible for the folding of the Kristallbrocken of this study. At room temperature, other slip systems in halite such as $\{111\}<110>$ and $\{100\}<011>$ have CRSS that are several times higher than required for the activation of the slip system $\{110\}<110>$ (cf. Scheffzük 1999). Consequently, if these shear stresses are not exceeded, or the orientation relative to the stress field is not suitable at all, then stress will be accommodated by brittle fracturing.

For the deformational behaviour, the size of the Kristallbrocken also plays a significant role. Although today most Kristallbrocken occur as broken relics, with sizes mainly ranging from 1 to up to $15 \mathrm{~cm}$ and being almost completely surrounded by matrix halite, this study demonstrates that they originally were 'single crystal-layers' of several decimetres in lateral size and an average thickness of at least $2-5 \mathrm{~cm}$ before having been broken apart (e.g. Fig. 1).

Another important aspect is the amount of solid inclusions. The folded Kristallbrocken (Fig. 12) has relatively few, but large inclusions, whereas the inclusion density of the other Kristallbrocken (Fig. 8) is higher, which thus most likely increased the rigidity of the Kristallbrocken and led to brittle fracturing. It is also possible that the bromide content of halite has a subordinate influence on the deformational behaviour. During the sedimentation of marine salts, bromide is incorporated into the crystal lattice of halite instead of chloride. As the ion radius of bromide (196 ppm) is larger than that of chloride $(181 \mathrm{ppm})$, the Kristallbrocken with higher bromide contents are potentially harder than those with lower bromide contents and thus more susceptible for brittle deformation. However, the bromide contents of the Kristallbrocken in Teutschenthal are generally relatively low (Küster et al. 2007a), ranging from about 60 to $90 \mathrm{ppm}$, and there is no significant difference between the bromide contents of the samples examined in this study. 


\section{Formation and deformation of the Kristallbrocken layers}

The results of this study do not only clearly indicate that the Kristallbrocken pieces from Teutschenthal formed larger 'single crystal-layers' before deformation (Figs. 8, 10), but also imply that the individual Kristallbrocken pieces from other locations with stronger deformation, like for example in the rock salt cube from the Asse salt mine (Fig. 1), originally also formed large monocrystalline layers. This allows us to postulate that the Kristallbrocken fabrics from Teutschenthal represent an earlier stage of deformation of the 'single crystal-layers' than the Kristallbrocken fabrics from locations with more intensely deformed rock salt. Finally, the questions arise how and when did such large monocrystalline layers form and when did they deform? Three models can be discussed (Fig. 18):

In model $\mathrm{A}$, at first, fine grained halite and sulphate crystals are precipitated and form a polycrystalline halite layer. In a second stage, this layer is subjected to syndiagenetic grain growth, e.g. by grain boundary area reduction or coalescence, that finally leads to the formation of the 'single crystal-layer'. This monocrystalline Kristallbrocken layer is deformed in a third stage due to salt migrationrelated processes.

In model B, there is also a polycrystalline halite layer at the beginning. In a second stage, this unconsolidated polycrystalline layer is deformed, for example by slump processes, and then subjected to diagenetic grain growth. Although the resulting single crystals look similar to the Kristallbrocken observed in this study, this model seems to be quite unlikely, as for example the grain growth process is not expected to form a single crystal in a 'bent' way and there would be no fracture between the Kristallbrocken pieces that look like having been moved passively against each other.

In model C, the Kristallbrocken layer would be a primarily grown, very large single crystal that deforms in a second stage during salt migration-related process. This model might be a possible alternative to model A, but it is quite difficult to explain the primary growth of such large monocrystalline layers, especially because ancient or modern analogues are not known.

For us, model A seems to be the most probable model as it well explains the microstructures observed in the rock salt of Teutschenthal. Furthermore, it is in line with the supposition of Simon (1972), who also took 'breaking apart of formerly continuous crystal layers' into consideration. Most of the Kristallbrocken have been deformed by brittle deformation for the reasons discussed above, but in some special cases, bending of the single crystal was also possible, which has been evidenced by the results of this study. The Kristallbrocken relics are also subjected to dynamic recrystallisation, which usually starts at the boundaries of this halite type resulting in an oval-shaped appearance, but can also take place in the highly stressed bending area of bent or folded Kristallbrocken. In the more intensely deformed Stassfurt rock salt of, e.g. Morsleben or Gorleben, the Kristallbrocken often occur only as relics or have been already completely recrystallised.

\section{Conclusions}

In this study, the deformation characteristics as well as the local CPOs of the Kristallbrocken were investigated. The most distinguishing feature of the Kristallbrocken in comparison to the halite matrix is that they show both ductile and brittle deformational behaviour. With the local $\mathrm{X}$-ray texture measurements, it could be clearly evidenced that the Kristallbrocken are single crystals and that separated pieces of the Kristallbrocken formerly formed one single monocrystalline halite layer. Furthermore, the results demonstrate that the presented X-ray texture goniometer configuration is suitable to analyse such monocrystalline structures in a quick and efficient way.

The monocrystallinity of the Kristallbrocken and their formerly large size explain the clearly stronger rheological properties of this halite type compared to the surrounding fine- to coarse-grained polycrystalline rock salt. In addition, the rigidity of this halite type is further enhanced by the partially high solid inclusion content. The bulk texture of the folded Kristallbrocken clearly illustrates that the monocrystalline structure was bent or folded as a whole. The deformation mechanism is assumed to be a kind of flexural-shear folding, with the lattice planes of the single crystal operating as shear planes. The most probable slip system seems to be $\{110\}<110\rangle$, which shows the lowest CRSS in halite at all temperatures. To enable such a bending process, we suppose that the crystal lattice of the Kristallbrocken must have a certain orientation in respect to the stress field, and the solid inclusion content is relatively low.

From the results of this study, it can be inferred that the Kristallbrocken fabrics from Teutschenthal represent an earlier stage of deformation of the 'single crystal-layers' than the Kristallbrocken fabrics from locations with more intensely deformed Stassfurt rock salt. For the formation and development of the Kristallbrocken, model A (Fig. 18) seems for us to be the model that explains the observed microstructures in the best way.

Acknowledgments This study was performed as part of the project No. 9Y3215020000 financed by the Federal Institute for Geosciences and Natural Resources (BGR), Hannover (Germany). Bernd Leiss acknowledges financial support by the German Federal Ministry of Education and Research (DUBGOE1-7 und 8) and the 
VolkswagenStiftung for financing the X-ray texture goniometer. We are grateful to Otto Schulze for helpful discussion on the deformational behaviour of the Kristallbrocken. Thanks to Adolf Hofmann for photographic support. We greatly appreciate helpful reviews of Chr. Scheffzük and an anonymous reviewer.

Open Access This article is distributed under the terms of the Creative Commons Attribution Noncommercial License which permits any noncommercial use, distribution, and reproduction in any medium, provided the original author(s) and source are credited.

\section{References}

Anderson RY, Dean WE, Kirkland DW, Snider HI (1972) Permian Castile varved evaporite sequence, West Texas and New Mexico. Geol Soc Am Bull 83:59-85. doi:10.1130/0016-7606 (1972)83[59:PCVESW]2.0.CO;2

Bachmann K (1985) Mineralogische und geochemische Untersuchungen an Bohrkernen des Staßfurt-Steinsalzes im Salzstock Asse. Kali und Steinsalz 9:132-138

Behlau J, Mingerzahn G (2001) Geological and tectonic investigations in the former Morsleben salt mine (Germany) as a basis for the safety assessment of a radioactive waste repository. Eng Geol 61:83-97. doi:10.1016/S0013-7952(01)00038-2

Bornemann O (1987) Die geologische Erkundung des Salzstocks Gorleben. Kerntechnik 50:138-142

Bornemann O (1991) Zur Geologie des Salzstocks Gorleben nach den Bohrergebnissen. BfS-Schriften 4:1-67

Bornemann O, Fischbeck R, Bäuerle G (2000) Investigation of deformation textures of salt rock from various Zechstein units and their relationship to the formation of the salt diapirs in NW Germany. In: Geertman RM (ed) 8th World salt symposium, vol 1. Elsevier, Amsterdam, pp 89-94

Bunge HJ, Klein H (1996) Determination of quantitative, highresolution pole figures with the area detector. Z Metallkunde 87:465-475

Carter NL, Hansen FD (1983) Creep of rock salt. Tectonophys 92:275-333. doi:10.1016/0040-1951(83)90200-7

Carter NL, Heard HC (1970) Temperature and rate dependent deformation of halite. Am J Sci 269:193-249

Carter NL, Horsemann ST, Russel JE, Handin J (1993) Rheology of rocksalt. J Struct Geol 15:1257-1271. doi:10.1016/0191-8141 (93) $90168-\mathrm{A}$

Czapowski G (1986) "Internal lamination" in halite rocks. Prz Geol 4:202-204

Czapowski G (1987) Sedimentary facies in the oldest rock salt (Na1) of the Leba elevation (Northern Poland). In: Peryt TM (ed) The Zechstein facies in Europe. Lecture notes in earth sciences, vol 10. Springer, Berlin, pp 207-224

Czapowski G, Antonowicz L, Peryt TM (1990) Facies and palaeogeography of the Zechstein (upper Permian) Older Halite (Na2) in Poland. Bull Pol Acad Sci Earth Sci 38:45-55

Czapowski G, Peryt T, Antonowicz L (1993) Facies and palaeogeography of the Zechstein (upper Permian) Oldest Halite (Na1) in Poland. Bull Pol Acad Sci Earth Sci 41:217-227

Downs RT, Bartelmehs KL, Gibbs GV, Boisen MB Jr (1993) Interactive software for calculating and displaying X-ray or neutron powder diffractometer patterns of crystalline materials. Am Mineral 78:1104-1107

Griffith AA (1924) The theory of rupture. In: Bienzo CB, Burgers JM (eds) Proceedings of the 1st international congress for applied mechanics, Delft, Netherlands, pp 55-63
Guillope M, Poirier JP (1979) Dynamic recrystallization during creep of single-crystalline halite: an experimental study. J Geophys Res 84:5557-5567. doi:10.1029/JB084iB10p05557

Helming K (1995) Texturapproximation durch Modellkomponenten. Habilitationsschrift, Technical University of Clausthal, $119 \mathrm{pp}$

Helming K, Eschner T (1990) A new approach to texture analysis of multiphase materials using a texture component model. Cryst Res Technol 25:K203-K208. doi:10.1002/crat.2170250828

Herrmann AG (2000) Br-Profil für das Staßfurt-Steinsalz des Salzstocks Gorleben. Kali und Steinsalz 13:57-67

Hofrichter E (1972) Behälterlose Speicherung von Energieträgern in ausgesolten Kavernen-geologisch-lagerstättenkundliche Probleme. Erdöl-Erdgas-Z 88:284-294

Hofrichter E (1974) Geologische Bearbeitung von KavernenspeicherProjekten in Salzstöcken Nordwestdeutschlands. Erdöl Kohle 27:190-194

Hunsche U, Schulze O (1994) Das Kriechverhalten von Steinsalz. Kali und Steinsalz 11:238-255

Jackson MPA, Talbot CJ (1986) External shapes, strain rates and dynamics of salt structures. Geol Soc Am Bull 97:305-323. doi: 10.1130/0016-7606(1986)97<305:ESSRAD > 2.0.CO;2

Jagsch R, Theylich H (1999) Speichergeologische und geotechnische Bedingungen an den Kavernenstandorten Teutschenthal und Bernburg. In: Hartmann O (ed) Kali-, Steinsalz und Kupferschiefer in Mitteldeutschland. pp 115-129

Jaritz W (1973) Zur Entstehung der Salzstrukturen Nordwestdeutschlands. Geol Jahrb A 10:1-77

Jaritz W (1983) Das Konzept der Erkundung des Salzstocks Gorleben von Übertage und die Festlegung von Schachtansatzpunkten. Neues Jahrb Geol Paläontol Abh 166:19-33

Jaritz W (1993) Die geowissenschaftliche Untersuchung des Salzstocks Gorleben auf seine Eignung für ein Endlager für radioaktive Abfälle-Stand 1993. Geol Jahrb A 142:295-304

Jung W (1968) Die Ausbildung des Staßfurtsteinsalzes (Na2) im südöstlichen Harzvorland. Bergakademie 20:509-515

Käding K-C (1978) Stratigraphische Gliederung des Zechsteins im Werra-Fulda Becken. Geol Jahrb Hessen 106:123-130

Käding K-C (2000) Die Aller-, Ohre-, Friesland- und Fulda-Folge (vormals Bröckelschiefer-Folge)—Stratigraphie und Verbreitung im Zechstein-Becken. Kali und Steinsalz 13:86-96

Kendall AC (1992) Evaporites. In: Walker RG, James NP (eds) Response to sea level changes. Geological Association of Canada, Ottawa, pp 375-409

Kockel F (1998) Salt problems in Northwest Germany and the German North Sea sector. J Seism Explor 7:219-235

Kocks UF, Tomé C, Wenk H-R (1998) Texture and anisotropy. Preferred orientations in polycrystals and their effect on materials properties. Cambridge University Press, Cambridge

Küster Y, Schramm M, Bornemann O, Leiss B (2007a) Bromide characteristics in bedded and domal rock salts of the Stassfurt formation (Zechstein 2): implications for the influence of salt migration-related processes. Geophys Res Abstr 9:03369

Küster Y, Schramm M, Leiss B (2007b) Different types of solid inclusions as indicators for the formation of laminated halite beds of Late Permian rock salt sequences. Geophys Res Abstr 9:03410

Küster Y, Schramm M, Bornemann O, Leiss B (2008) Bromide distribution characteristics of different Zechstein 2 rock salt sequences of the Southern Permian Basin: a comparison between bedded and domal salts. Sedimentol. doi:10.1111/j-1365-3091. 2008.01038.x

Lachmann R (1914) Diskussionsbemerkungen zum Vortrag von E. Seidl "Die Steinsalzablagerungen des oberen Zechsteins bei Schönebeck nach den Grubenaufschlüssen des Graf-MoltkeSchachtes". Z Dtsch Geol Ges 65:62-64 
Lawn BR, Wilshaw TR (1975) Fracture of brittle solids. Cambridge University Press, Cambridge

Leiss B (2005) New techniques, measuring strategies and applications of conventional X-ray texture analysis. Conference abstracts 'deformation mechanism, rheology and tectonics', Zurich, Switzerland

Leiss B, Barber DJ (1999) Mechanisms of dynamic recrystallization in naturally deformed dolomite inferred from EBSP analyses. Tectonophys 303:51-69. doi:10.1016/S0040-1951(98)00258-3

Leiss B, Molli G (2003) "High-temperature" texture in naturally deformed Calcite marble from the Alpi Apuane, Italy. J Struct Geol 25:649-658. doi:10.1016/S0191-8141(02)00148-7

Leiss B, Ullemeyer K (2006) Neue Perspektiven der Texturanalytik von Gesteinen mit konventioneller Röntgenbeugung. In: Philipp SL, Leiss B, Vollbrecht A, Tanner D, Gudmundsson A (eds) Symposium' Tektonik, Struktur- und Kristallingeologie', Universitätsverlag Göttingen, vol 11. pp 128-130

Leiss B, Siegesmund S, Weber K, Olesen NØ (1994) Localized texture components of a naturally deformed dolomite-a contribution to the analysis of texture-forming processes. In: Bunge H-J, Siegesmund S, Skrotzki W, Weber K (eds) Textures of geological materials. DGM Press, Oberursel, pp 261-275

Lotze F (1957) Steinsalz und Kalisalze-1. Allgemein-geologischer Teil. Bornträger, Berlin

Pape T, Michalzik D, Bornemann O (2002) Chevronkristalle im Kristallbrockensalz (Zechstein 2) des Salzstocks GorlebenPrimärgefüge salinarer Flachwassersedimentation im Zechsteinbecken. Z Dtsch Geol Ges 153:115-129

Passchier CW, Trouw RAJ (1998) Microtectonics. Springer, Berlin, pp 289

Popp T, Kern H, Schulze O (1999) Lithologische Variabilität der petrophysikalischen und mineralogisch-gefügekundlichen Eigenschaften des älteren Steinsalzes (z2) aus dem Salzstock Gorleben. Meyniana 51:55-75

Popp T, Kern H, Schulze O (2001) Evolution of dilantancy and permeability in rock salt during hydrostatic compaction and triaxial deformation. J Geophys Res 106:4061-4078. doi: 10.1029/2000JB900381

Prior DJ, Boyle AP, Brenker F, Cheadle MC, Day A, Lopez G, Peruzzo L, Potts GJ, Reddy S, Spiess R, Timms NE, Trimby P, Wheeler J, Zetterström L (1999) The application of electron backscatter diffraction and orientation contrast imaging in the SEM to textural problems in rocks. Am Mineral 84:1741-1759

Richter-Bernburg G (1955) Über salinare Sedimentation. Z Dtsch Geol Ges 105:593-645

Roedder E (1984) The fluids in salt. Am Mineral 69:413-439

Schauberger O, Kühn R (1959) Über die Entstehung des alpinen Augensalzes. N Jahrb Geol Paläontol, Monatshefte 6:247-259

Scheffzük CM (1999) Neutronographische Texturanalysen und Mikrostrukturuntersuchungen natürlicher und triaxial verformter Halite. Dissertation RWTH Aachen, Scientific Technical Report STR99/15, GeoForschungsZentrum Potsdam

Schramm M, Bornemann O, Siemann M, Wilke F, Geluk M (2005) Correlation between bromine concentrations in halites and their stratigraphical position in Zechstein 2 salt deposits of NorthWest Europe. Geophys Res Abstr 7:04552

Schreiber BC, Friedman GM, Decima A, Schreiber E (1976) Depositional environments of Upper Miocene (Messinian) evaporite deposits of the Silician Basin. Sedimentol 23:729760. doi:10.1111/j.1365-3091.1976.tb00107.x

Schulze G (1958) Beitrag zur Stratigraphie und Genese der Steinsalzserien I-IV des mitteldeutschen Zechsteins unter besonderer
Berücksichtigung der Bromverteilung. Freiberger Forschungshefte A 123:175-192

Schulze G (1960) Stratigraphie und genetische Deutung der Bromverteilung in den mitteldeutschen Steinsalzlagern des Zechsteins. Freiberger Forschungshefte C 83:1-116

Schünemann F (1913) Vorläufige Mitteilung über einzelne Ergebnisse meiner Untersuchungen auf den Kaliwerken des Staßfurter Sattels. Z praktische Geol 21:205-216

Simon P (1972) Stratigraphie und Bromgehalt des Staßfurt-Steinsalzes (Zechstein 2) im hannoverschen Kalisalzbergbaugebiet. Geol Jahrb 90:67-126

Simon P, Haltenhof M (1970) Feinstratigraphie, Fazies und Bromgehalt des Staßfurt-Steinsalzes (Zechstein 2) im Kali- und Steinsalzbergwerk "Asse" (Schacht 2) bei Baunschweig. Geol Jahrb 88:159-202

Skrotzki W (1984) An estimate of the brittle to ductile transition in salt. In: Hardy RH Jr, Langer M (eds) Proceedings of the 1st conference on the mechanical behaviour of salt, Pennsylvania State University. Mechanical behaviour of salt I. Series on rock and soil mechanics, vol 9. Trans Tech Publications, ClausthalZellerfeld, pp 381-388

Skrotzki W, Haasen P (1981) Hardening mechanisms of ionic crystals on (110) and (100) slip planes. J Phys 42:C3-119-C3-148

Skrotzki W, Frommeyer G, Haasen P (1981) Plasticity of polycrystalline ionic solids. Phys Status Solidi A 66:219-228. doi:10. 1002/pssa.2210660125

Smith DB (1979) Rapid marine transgressions and regressions of the Upper Permian Zechstein Sea. J Geol Soc London 136:155-156. doi:10.1144/gsjgs.136.2.0155

Taylor JCM (1998) Upper Permian-Zechstein. In: Glennie KW (ed) Petroleum geology of the North Sea, 4th edn. Blackwell Science, Oxford, pp 174-211

Trimby PW, Drury MR, Spiers CJ (2000) Misorientations across etched boundaries in deformed rocksalt: a study using electron backscatter diffraction. J Struct Geol 22:81-89. doi:10.1016/ S0191-8141(99)00126-1

Trusheim F (1960) Mechanism of salt migration in North Germany. AAPG Bull 44:1519-1540

Twiss RJ, Moores EM (1992) Structural geology. W.H. Freeman and Company, New York

Urai JL, Means WD, Lister GS (1986) Dynamic recrystallization of minerals. In: Hobbs BE, Heard HC (eds) Mineral and rock deformation: laboratory studies-the Paterson volume, vol 36. Geophysical Monograph, Washington, pp 161-199

Watanabe T, Peach CJ (2002) Electrical impedance measurement of plastically deforming halite rocks at $125^{\circ} \mathrm{C}$ and $50 \mathrm{MPa}$. J Geophys Res 107(B1):1-12. doi:10.1029/2001JB000204

Wcislak L, Klein H, Bunge HJ, Garbe U, Tschentscher T, Schneider JR (2002) Texture analysis with high-energy synchrotron radiation. J Appl Cryst 35:82-95. doi:10.1107/S0021889801019902

Wilke F, Bornemann O, Behlau J, Mingerzahn G (2002) Anwendung geologischer Untersuchungsmethoden des Salzstockes Gorleben auf Kavernenprojekte im mitteleuropäischen Zechsteinbecken. Erdöl Erdgas Kohle 11:518-522

Ziegler PA (1981) Evolution of sedimentary basins in North-West Europe. In: Illing LV, Hobson GD (eds) Petroleum geology of the continental shelf of Northwest Europe. Heyden, London, pp 3-39

Ziegler PA (1990) Geological Atlas of Western and Central Europe. Shell Internationale Petroleum Maatschappij B.V., 2nd edn. Geological Society of London/Elsevier, London/Amsterdam, pp 239 